\title{
Potential Role of Flavivirus NS2B-NS3 Proteases in Viral Pathogenesis and Anti-flavivirus Drug Discovery Employing Animal Cells and Models: A Review
}

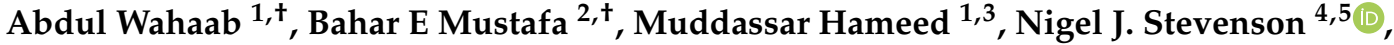

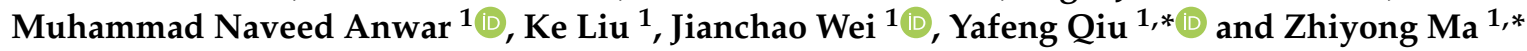

Citation: Wahaab, A.; Mustafa, B.E.;

Hameed, M.; Stevenson, N.J.;

Anwar, M.N.; Liu, K.; Wei, J.; Qiu, Y.; $\mathrm{Ma}, \mathrm{Z}$. Potential Role of Flavivirus NS2B-NS3 Proteases in Viral Pathogenesis and Anti-flavivirus Drug Discovery Employing Animal Cells and Models: A Review. Viruses 2022, 14, 44. https://doi.org/ $10.3390 / \mathrm{v} 14010044$

Academic Editors: Denis E. Kainov and Valentyn Oksenych

Received: 26 October 2021

Accepted: 23 December 2021

Published: 28 December 2021

Publisher's Note: MDPI stays neutral with regard to jurisdictional claims in published maps and institutional affiliations.

Copyright: (c) 2021 by the authors. Licensee MDPI, Basel, Switzerland. This article is an open access article distributed under the terms and conditions of the Creative Commons Attribution (CC BY) license (https:// creativecommons.org/licenses/by/ $4.0 /)$.
1 Shanghai Veterinary Research Institute, Chinese Academy of Agricultural Science, Shanghai 200241, China; wahaaabwahaaab@gmail.com (A.W.); muddassarh@vt.edu (M.H.); dr.naveed903@gmail.com (M.N.A.); liuke@shvri.ac.cn (K.L.); jianchaowei@shvri.ac.cn (J.W.)

2 Sub Campus Toba Tek Singh, University of Agriculture, Faisalabad 36050, Pakistan; bahar.mustafa@uaf.edu.pk

3 Department of Biomedical Sciences and Pathobiology, College of Veterinary Medicine, Virginia Polytechnic Institute, State University, Fralin Life Sciences Building, 360 W Campus Blacksburg, Blacksburg, VA 24061, USA

4 Royal College of Surgeons in Ireland, Medical University of Bahrain, Busaiteen, Adliya 15503, Bahrain; n.stevenson@tcd.ie

5 Viral Immunology Group, School of Biochemistry and Immunology, Trinity Biomedical Sciences Institute, Trinity College Dublin, D02 R590 Dublin, Ireland

* Correspondence: yafengq@shvri.ac.cn (Y.Q.); zhiyongma@shvri.ac.cn (Z.M.); Tel.: +86-21-3468-3635 (Y.Q.); +86-21-3429-3139 (Z.M.); Fax: +86-21-5408-1818 (Y.Q. \& Z.M.)

$+\quad$ These two authors contributed equally to this work.

\begin{abstract}
Flaviviruses are known to cause a variety of diseases in humans in different parts of the world. There are very limited numbers of antivirals to combat flavivirus infection, and therefore new drug targets must be explored. The flavivirus NS2B-NS3 proteases are responsible for the cleavage of the flavivirus polyprotein, which is necessary for productive viral infection and for causing clinical infections; therefore, they are a promising drug target for devising novel drugs against different flaviviruses. This review highlights the structural details of the NS2B-NS3 proteases of different flaviviruses, and also describes potential antiviral drugs that can interfere with the viral protease activity, as determined by various studies. Moreover, optimized in vitro reaction conditions for studying the NS2B-NS3 proteases of different flaviviruses may vary and have been incorporated in this review. The increasing availability of the in silico and crystallographic/structural details of flavivirus NS2B-NS3 proteases in free and drug-bound states can pave the path for the development of promising antiflavivirus drugs to be used in clinics. However, there is a paucity of information available on using animal cells and models for studying flavivirus NS2B-NS3 proteases, as well as on the testing of the antiviral drug efficacy against NS2B-NS3 proteases. Therefore, on the basis of recent studies, an effort has also been made to propose potential cellular and animal models for the study of flavivirus NS2B-NS3 proteases for the purposes of exploring flavivirus pathogenesis and for testing the efficacy of possible drugs targets, in vitro and in vivo.
\end{abstract}

Keywords: flaviviruses; NS2B-NS3 proteases; genome organization; pathogenesis; characterization; antiviral drug target; in vitro and in vivo models

\section{Introduction}

The genus, Flavivirus (family Flaviviridae), consists of more than approximately 70 viruses, out of which the majority are arthropod-borne viruses, including dengue virus (DENV), Japanese encephalitis virus (JEV), Zika virus (ZIKV), and West Nile virus (WNV) [1-4]. They are so named because they were found to be associated with the causation of yellow fever in humans (the Latin word "flavus" means "yellow") [3,4]. More 
than twenty kinds of flaviviruses are responsible for the causation of a myriad of zoonotic diseases. Arthropod-borne flaviviruses are usually cycled among widely diverse avian and mammalian hosts (Figure 1) [5-14]. Viral persistence is a staple for pathogenesis and is maintained, predominately, without any obvious detrimental effects on the host biology. Their replication and persistence are also well documented in cell cultures [15-19]. Approximately $40 \mathrm{spp}$. of flaviviruses are responsible for a variety of diseases in humans. Many of these viruses are capable of causing high mortality and morbidity rates [20]. The family comprises four main genera, which include Pestivirus, Pegivirus, Hepacivirus, and Flavivirus. Within each genus, the virus may be subdivided into various antigenic groups, based on the serology or the molecular phylogeny, and categorized into different clusters, clades, and subspecies [21]. Morphologically, flaviviruses have a size of approximately $500 \mathrm{~A}^{\circ}$ and consist of the RNA genome (positive-sense single-stranded RNA that is linear), enclosed in a capsid, which is further surrounded by an envelope. RNA is infectious in nature. The approximately $11 \mathrm{~kb}$ (although the genome length varies in different members) genome of flaviviruses encodes a single open reading frame (ORF) and untranslated regions (UTRs), which are present at $5^{\prime}$ and $3^{\prime}$ of the genome. The ORF contains three basic structural proteins (SPs) and seven nonstructural proteins (NS proteins). The SPs are located at the $5^{\prime}$ end of the RNA genome, and they include: a core protein, also known as a nucleocapsid (C protein); an envelope protein (E protein), which is often glycosylated, and that is also a major antigen that is subjected to neutralization by antibodies; and a nonglycosylated membrane protein (M protein). The nonstructural proteins (NS1, NS2A, NS2B, NS3, NS4A, NS4B, and NS5), which are present at the $3^{\prime}$ end of the genome, have a variety of functions, and are primarily involved in RNA replication, virus assembly, and the modulation of host responses [22-24]. Among the NS proteins, only NS3 and NS5 are known to perform a variety of enzymatic reactions. NS3 encodes the RNA helicase $[25,26]$ serine protease [24,27], RNA triphosphatase (RTPase) [27,28], and nucleocapsid triphosphatase (NTPase) activities [29-31]. In particular, NS2B and NS3 are mainly responsible for performing the proteolytic cleavage in the virus (the remainder of the cleavage is performed by the proteases from the cellular origin [23,32-34]), in addition to encoding guanyl and methyltransferase (GTase and MTase activities) [35-37]. Flaviviruses replicate inside macrophages, monocytes, and dendritic cells, and they tend to replicate in the cytoplasm of the host cell in order to induce a variety of cytopathic alternations in the cells [38,39]. Regardless of the genus, the attachment of the virus to the cells is almost always mediated by the E protein $[14,40,41]$. The phenomenon of receptor-mediated endocytosis is manipulated for viral entry into the cells [41-44]. The low $\mathrm{pH}$ of the endosome triggers the fusion of the host cell membrane and the virus, causing the release of RNA in the cytoplasm of the cell. Once inside the cell, the cytoplasm is the site where viral replication takes place [45]. However, it is important to mention here that flaviviruses do not completely stop the host cell's RNA and protein synthesis $[46,47]$. The assembly of the virion has been observed to occur in the endoplasmic reticulum (ER), as well as in the cell membrane in the case of mosquito cells. The final release of the virion occurs through exocytosis [48]. The subviral particles (SVPs) (without genome and capsid protein) consist only of a lipid bilayer, along with bound prM-E complexes, and are produced as a byproduct of the viral assembly process. After final processing and release from the ER, these SVPs are released as whole noninfectious particles [49]. The functional and structural insights of flavivirus proteases summarized in this review may advance our current knowledge of flavivirus replication and accelerate the efforts for the development of vaccines and/or broad-spectrum antivirals against flaviviruses. 


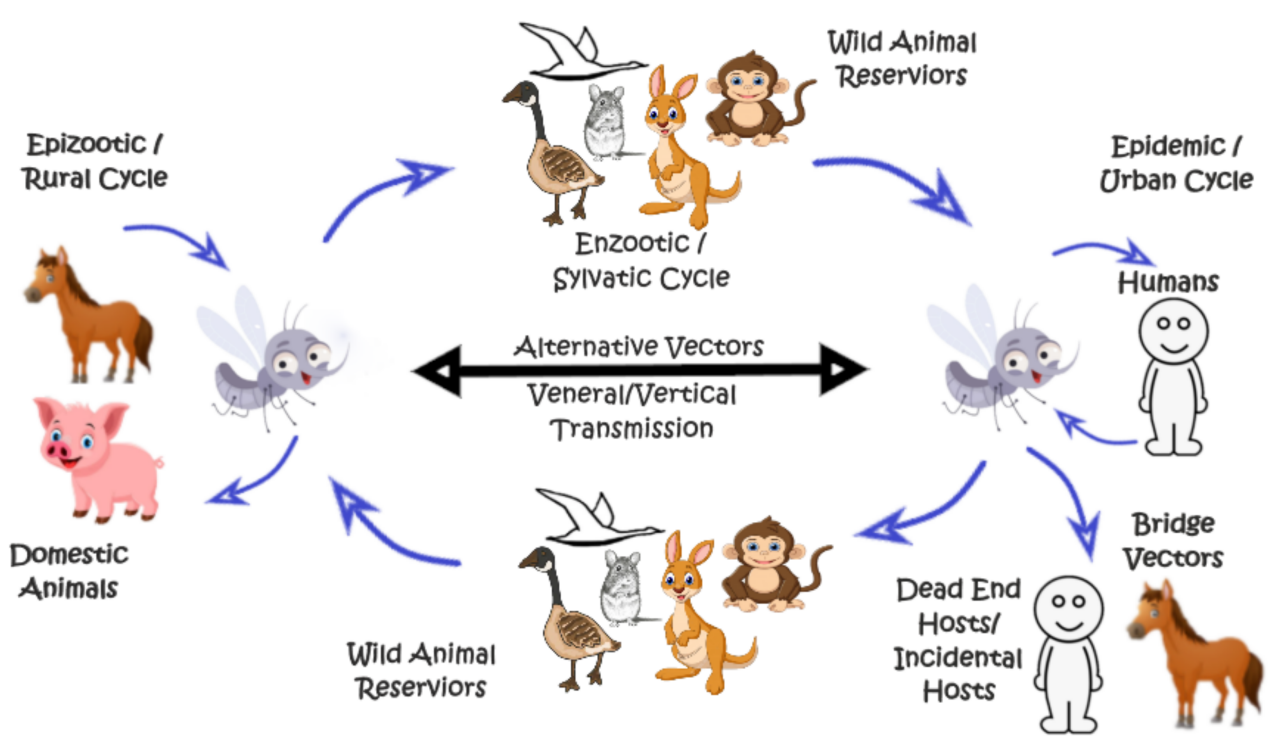

Figure 1. Typical life/transmission cycle of arthropod-borne Flaviviruses.

\section{Structure and Role of NS3 and NS3 Protease Domain in Flavivirus Replication}

The genetic similarity between the members of the flavivirus genus predicts the main features necessary for the viral replication cycle [50]. The NS3 is one of the major viral proteins possessing enzymatic function. It is found to be the most conserved among the viral proteins, and it exhibits approximately $65 \%$ sequence identity among JEV, WNV, DENV, YFV, and ZIKV (Figure 2) [51]. As described previously, there are two major domains of this protein, which are the RNA helicase and protease domains, connected through a short linker (flexible). The three-dimensional structure of NS3 proteins has been well documented and resolved for various flaviviruses. However, depending on the virus replication stage, different conformations can exist [51,52]. For instance, the binding of RNA is one event that can induce a conformational change $[53,54]$. The $\mathrm{N}$-terminal domain of the flavivirus NS3 protein consists of protease domains that contain four homologous sequences to serine protease. Three of them form catalytic domains, whereas the fourth helps in substrate binding [55]. It has been suggested that the specificity of the substrate binding is because of an aspartic acid residue, which is located in the lower portion of the binding pocket [56]. The exact site for the proteolytic cleavage depends on the cleavage site sequence, and it may vary among different members; however, the majority of these sites contain two basic residues, which are followed by a side chain within the viral polyprotein [57].

\section{Structure and Role of NS2B and NS2B Hydrophilic Domain in Flavivirus Replication}

NS2B consists of approx. 130 amino acids, and is a type of small integral membrane protein, having a molecular weight of $14 \mathrm{kD}$. It consists of three hydrophobic domains (which are supposed to be part of the transmembrane domain) and a central hydrophilic domain $[58,59]$. Studies have suggested that the central hydrophilic domain is required for the activation of NS3, and that any mutations in it can cause the defective protease activity of NS3, or may even cause NS3 instability, leading to faulty viral assembly [58,60-65]. NS2B (H) (hydrophilic domain of NS2B) essentially acts as a cofactor for the protease activity of the NS3 protein. The initial characterization of the cofactor requirement for various flaviviruses has revealed that the minimal essential region for protease activity is positioned in a 40-50 residue central hydrophilic segment of NS2B (amino acid 45 to 95 ) $[32,58,66,67]$. NS2B contains a hydrophilic region, the central region of which contains a $\beta$-barrel, which folds around the $\beta$-barrel of the NS3 protease for its stability [55]. Upon substrate binding, conformational changes occur in the NS2B (C-terminal domain), which leads to the stability of $\beta$ - hairpin, which becomes the component of the active site $[55,68]$. The active NS2B 
(H)-NS3 protease is essential for the cleavage at the NS2A/NS2B, NS2B/NS3, NS3/NS4A, and NS4B/NS5 junctions $[69,70]$. Moreover, it has also been proposed that the cleavage of capsid protein may also be mediated through the NS2B-NS3 protease [71]. The NS2B-NS3 interaction may also cause the tethering of NS3 at the membrane, causing replicase complex anchoring at the compartment membranes [72]. Both NS2B(H) and NS3 are associated with the membrane structures (virus-induced) [73]. This suggests that the interaction of NS3 with NS2B $(\mathrm{H})$ is mandatory for its membrane localization [63].

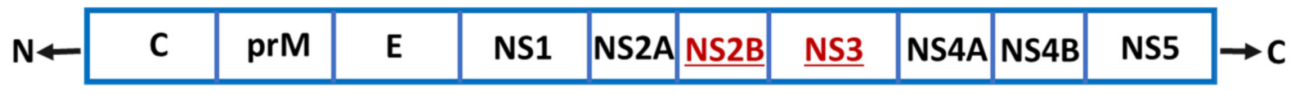

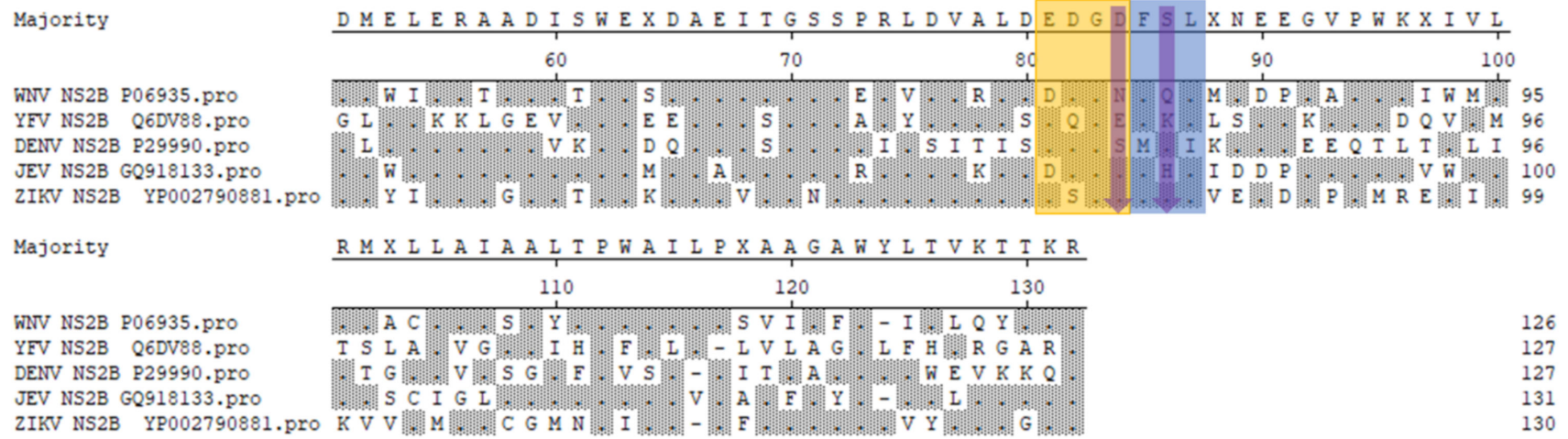

Majority GG-VLWDVPSPKEXKKGET-TDGVYRIMTRGLLGSSQAGVGVMQEGVEHT

WNV NS3 P06935.pro YFV NS3 Q6DV88.pro DENV NS3 P29g90.pro JEV NS3 GQ918133.pro

Majority

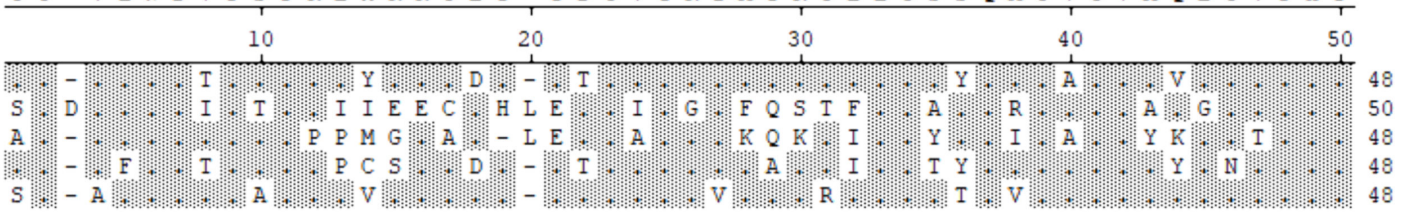

WNV NS3 P06935.pro

YFV NS3 Q6DV88.pro DENV NS3 P29990.pro

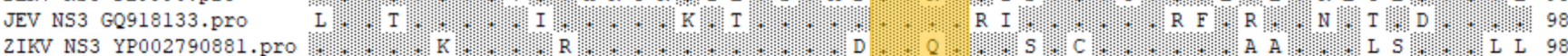

Majority

MWHVTRGAALMSGEGRLDPYWGSVKEDLVAYGGPWKLDGKWDGXDEVQVI

60

$\begin{array}{lll}80 & 90 & 100\end{array}$

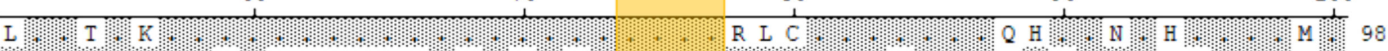

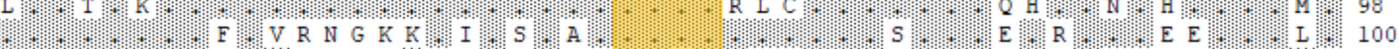

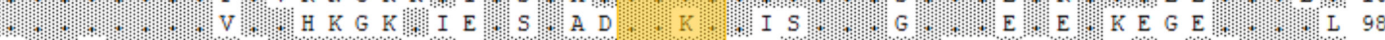

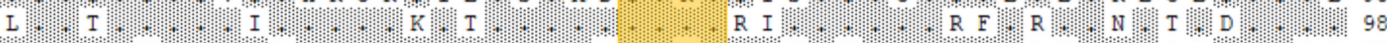

AVEPGKNAVNVQTKPGVFKTPN-GEIGAVALDYPXGISGSPIVIKNGDVI

WNV NS3 P06935.pro YFV NS3 Q6DV88.pro DENV NS3 P29990.pro JEV NS3 GQ918133.pro 2IKV NS3 YP002790881.pro

Majority

WNV NS3 P06935.pro YFV NS3 Q6DV88.pro DENV NS3 P29990.pro JEV NS3 GQ918133.pro 2IKV NS3 YP002790881.pro

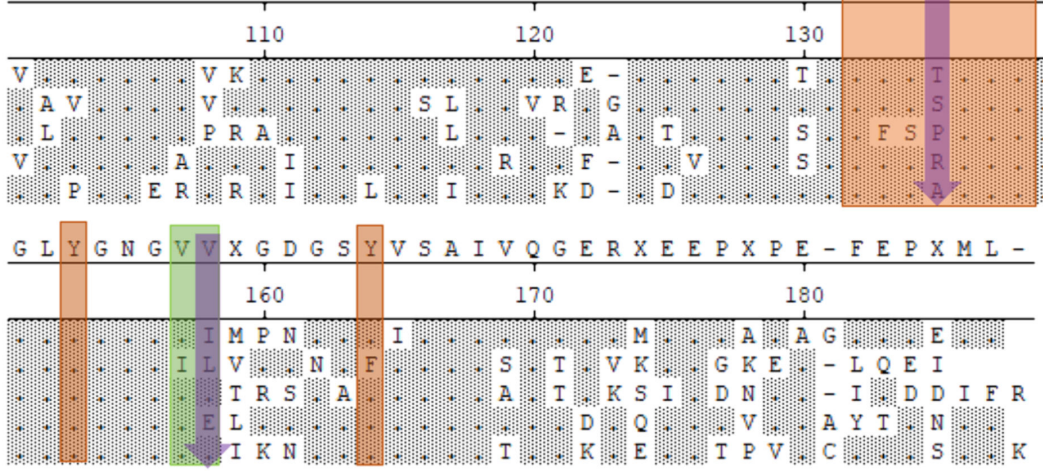
(1)

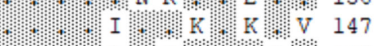
(t)
L
L L

Figure 2. Multiple sequence alignment of NS2B/NS3 protease from different flaviviruses (WNV, YFV, DENV2, JEV, and ZIKV). Residues located in four distinct substrate-binding pockets, i.e., S1, S2, S3, and S4, marked in orange, yellow, cyan, and green, respectively $[55,74]$. Nonconserved residues located at the binding pockets are marked in magenta arrowheads [75].

\section{Dengue Virus (DENV)}

A deletion analysis of NS2B in DENV has demonstrated the sufficient role of the central hydrophilic region as a cofactor of NS3 [66,76,77]. The dengue virus (DENV) 
possesses a polyprotein that is needed to be processed, and that has been found to undergo cleavage at the rER of the host by NS2B-NS3 (cytoplasmic side) and by host cell peptidase (luminal side) [24]. NS2B (a.a. 1394 to 1440) is required as a cofactor for NS3 protease (a.a. 1476 to 1660) [77] and is also involved in the recognition of the substrate [78]. In the dengue virus, NS2B often acts as a cofactor of NS3 (protease domain), and it consists of 130 amino acids (15 kDa) [79]. The $\mathrm{N}$ and $\mathrm{C}$ terminal domains are located in the cytoplasm. It is proposed to have a helical bundle that consists of approximately four alpha-helix subunits (1-4), which are short and transmembrane. Between the $\alpha 2$ and $\alpha 3$ subunits, it contains a central hydrophilic domain (consisting of 40 residues and that is highly conserved), which is responsible for its cofactor activity [80]. This domain leads to heterodimerization with the NS3 protease domain (noncovalently), and it results in the formation of a functional membrane-bound protease complex. This complex is needed for the appropriate localization and activation of the serine protease. There are suggestions that it is also needed for the trimerization of NS2B-NS3, although the exact mechanism remains to be elucidated [81]. In the open conformation of NS2B-NS3, the catalytic site is not wrapped by the cofactor, while in the closed conformation, it is needed for the appropriate recognition of the substrate, as well as for efficient proteolysis. Moreover, the latter is also the most predominant form of NS2B-NS3 in the solutions, whether it is ligand-bound or not [81,82]. The protease activity of the NS2B-NS3 leads to viral protein cleavage at NS2A/NS2B, NS2B/NS3 (through cis-cleavage), NS3/NS4A, and NS4B/NS5 (through trans-cleavage). This protease complex is also needed for the internal cleavage within the NS2A, NS4A, and NS3 helicases. Cleavage occurs at the dibasic motifs (RR, KR, $\mathrm{RK})$ at $\mathrm{P} 1$ and $\mathrm{P} 2$, and at a short chain amino acid at $\mathrm{P} 1^{\prime}(\mathrm{A}, \mathrm{G}$, or $\mathrm{S})$. The protease complex also cleaves the $C$ protein at the $C$ terminus (at dibasic motifs, which are conserved) $[63,82]$. Interestingly, while studying the noncofactor roles of NS2B, it has been shown that there is colocalization of the NS2B with dsRNA, which indicates that it might be a part of the replication complex [83]. Moreover, it has also been implicated in viral replication, its assembly, and release, and thus may contribute towards the cytopathic effects (in combination with NS2A) [84]. In DENV, the oligomerization of the NS2B with the host cell membrane may be mediated by its alpha-helical TMD (transmembrane domain). In human red blood cells (RBCs), the DENV NS2B has been shown to destabilize and increase the membrane permeability that leads to pore formation [85]. NS2B mutations at the Trp 62 residue resulted in the complete elimination of the cis-cleavage ability of the NS2BNS3 protease, while the substitution of alanine at Leu 75, Ile 77, and Ile 79 resulted in reduced proteolytic activity [86]. Recently, it has also been shown that NS2B (alone, or with NS3) interferes with type 1 interferon (IFN) production. This is conducted by specifically targeting the cyclic GMP-AMP synthetase (cGAS) for degradation. cGAS is required for binding with DNA (self or nonself) in the cytoplasm, and it activates a series of biochemical changes through signal transduction that ultimately results in STING activation, which is required for type 1 IFN generation. DENV NS2B causes the degradation of cGAS through the autophagy/lysosomal mediated pathway [87].

\section{Yellow Fever Virus (YFV)}

The yellow fever virus genome contains 10862 nucleotides, which encode a long precursor polyprotein. At the membranes of the ER, the generation of viral proteins occurs by the cleavage of the viral polyproteins. The cleavage of the viral structural proteins and NS4B (N-terminus) is mediated by signal peptidase, while the cleavage of the NS1-NS2A is mediated by the host protease (membrane-bound) in the host cell [88]. The cleavage of the remaining capsid protein (membrane-anchored), as well as the cotranslational cleavages, are mediated by the NS3 protease along with the NS2B cofactor [71,79,89-91]. The various cleavage sites include consensus (C/virion C, 2A/2B, 2B/3, 3/4A, 4A/2K, and 4B/5) and alternative sites $(\mathrm{aA} \alpha)$ [92]. The $\mathrm{N}$-terminal of the NS3 protein possesses a trypsin-like serine protease domain that preferentially cleaves the two adjacent basic amino acids, e.g., RR or KR, or, in some cases, QR, QK in the consensus sequence of G/ARR2S/G [58,61,92]. 
The conserved central region of NS2B, and the amino-terminal region of the NS3B, together form the NS2B-NS3 protease complex. Just as in DENV, the NS2B-NS3(pro) constitutes a stable complex that mediates the polyprotein substrate cleavage, both in the cis and the transform [58]. However, charged amino acids are important for this protein cleavage, as it has been determined that the mutations involving charged-alanine replacement at NS2B-NS3181 have demonstrated that they affect polyprotein processing [93].

\section{Zika Virus (ZIKV)}

Structural studies have shown that the NS2B-NS3 protease of ZIKV exists in two forms: a closed form and an open form. In the presence of a substrate or inhibitor, it usually adopts a closed conformation, while in the absence of the substrate or inhibitor, it is in open conformation [94,95]. It has been shown that NS2B surrounds the NS3 in such a way that it leads to the formation of $\beta$-hairpin, which then makes an important contribution to the formation of the S2 pocket of NS3 [94-96]. The NS2B of the Zika virus exhibits a higher level of disorderliness, especially from the 62-98 residue region (37 residues) [97,98]. Ultimately, NS2B interacts with NS3 in such a way that it leads to the cleavage of the polyprotein into a variety of functional proteins, which are important in viral replication and maturation [55].

\section{Japanese Encephalitis Virus (JEV)}

Japanese encephalitis (JE) is a vaccine-preventable disease caused by the Japanese encephalitis virus (JEV), which is primarily prevalent in Asia. The JEV is classified into a single serotype, with five genetically distinct genotypes, i.e., I, II, III, IV, and V, having an 11 $\mathrm{Kb}$ genome, comprising three structural and seven nonstructural proteins [99-102]. In JEV, the N-terminal 1/3rd (180 residues) of the NS3 contains protease active sites, which include His 51, Asp 75, and Ser 135 [103]. Just as in other flaviviruses, NS2B acts as the cofactor of the NS3 serine protease $[58,66]$. NS2B-NS3 proteases have been involved in carrying out a variety of important phases, e.g., RNA replication (viral), polypeptide cleavage, and the processing and assembly of viral particles [104,105]. The protease activity of the JEV NS2B/NS3 leads to the viral polyprotein cleavage of the capsid (internal), NS2A/NS2B, NS2B/NS3, and NS3/NS4A sites [32]. Moreover, NS2B-NS3 proteases may also play an important role in the immune evasion by the virus [105]. It has been shown that NS2B-NS3 proteases have been involved in the cleavage of interferon stimulators. In mice, this ability was found to play a critical role in enhanced viral replication, as well as in enhanced virulence [106]. Researchers have also demonstrated that certain mutations in the NS2BNS3 region (NS2B-99, NS3-78, and NS3-177) contribute to the enhanced infectivity of JEV (genotype I) in amplifying hosts [107]. In JEV, the residues, Ser 46 to Ile 60 (in particular Trp 53, Glu 55, and Arg 56), are essential for the NS3 protease activity (both cis- and transactivity), just as in DENV4 and YFV. The NS2B of JEV is found to exhibit $67 \%$ similarity with the WNV NS2B sequence, while it is found to exhibit $28-34 \%$ with other mosquito-borne flaviviruses [108].

\section{West Nile Virus (WNV)}

In the West Nile virus, just as in other flaviviruses, NS2B (25 kDa) consists of a transmembrane protein (hydrophobic) that is involved in the replication of the genome, the formation of the membranous structure, and the assembly of virions $[109,110]$. In order to obtain the association of the protease complex into virus-induced membranes, the domains at both the $\mathrm{N}$ and $\mathrm{C}$ terminals (residues at 59-62 and 75-87, respectively) play an important role [111]. Another study has shown that the mutation in NS2B at D(80)DD and G83 results in a reduction in the viral NS2B-NS3 protease activity, as well as replication [112]. The unwinding activity of RNA by NS3 is likely made possible after the association of NS2B with NS3 [73,113]. The exact mechanism by which NS2B acts as a cofactor is not completely understood; however, several studies have revealed that, in the presence of NS2B, there is a substantial rearrangement in the NS3 [55,68]. Crystal structures have shown that the NS2B (residue 49-88) tends to form a 
belt that surrounds the NS3 protease domain. This interaction then forces the NS3 to adopt active conformation $[55,77,109]$. The NS3 protein is a highly conserved protein that possesses serine protease activity at the N-terminal domain. As this protein lacks a transmembrane domain, after its cleavage from polyprotein, it either goes in the cytoplasm, or remains retained in the ER, where its enzymatic domains are needed [114,115]. Just as with other flaviviruses, it is only active in the presence of the NS2B cofactor, and, in the case of its absence, the NS3 protease domain remains inactive $[66,79,116]$. This complex (NS2B(H)-NS3) then cleaves the viral polyprotein into a variety of structural and nonstructural proteins [111,117]. The complex of NS2B-NS3 proteases has been found to localize within the convoluted membranes (CM) or para crystalline (PC) arrays, which suggests the possible involvement of the membranes in the proteolytic cleavage [78]. In WNV, the proteolytic activity of the NS3 (Pro), in association with NS2B (hydrophilic region; residue 50-97), has been demonstrated by employing an $E$. coli expression system [118]. Recently, crystal studies involving DENV and WNV NS2B-NS3 proteases have demonstrated that the residues, $51-57$ and $82-85$ of the NS2B, are important for the stabilization of the NS3 protease and the substrate recognition activity, respectively [55]. Sequence analysis and mutation studies have revealed that the determinants of the flavivirus NS2B protein (except in JEV), which control NS3 protease activation and activities, are located at the positions: Glu52-Leu53-Lys54- Lys55 of YFV [62,93]; Trp62, Leu75-Ser76-Ile77-Thr78Ile79, and Glu89-Glu90-Glu91- Glu92 of DENV-2 [86,119]; and Trp60, Gly68, Gln77, Gly81, and Val88 of Alkhurma virus (ALKV) [120]. It has also been reported that the NS2B-NS3 proteases were responsible for the apoptosis in human medulloblastoma cells through the activation of caspase-3 and the mitochondrial mediated pathway [121]. The cleavage sites, which are proteolytically processed by the NS2B-NS3 proteases in the polyproteins of various flaviviruses, are summarized in Figure 3.

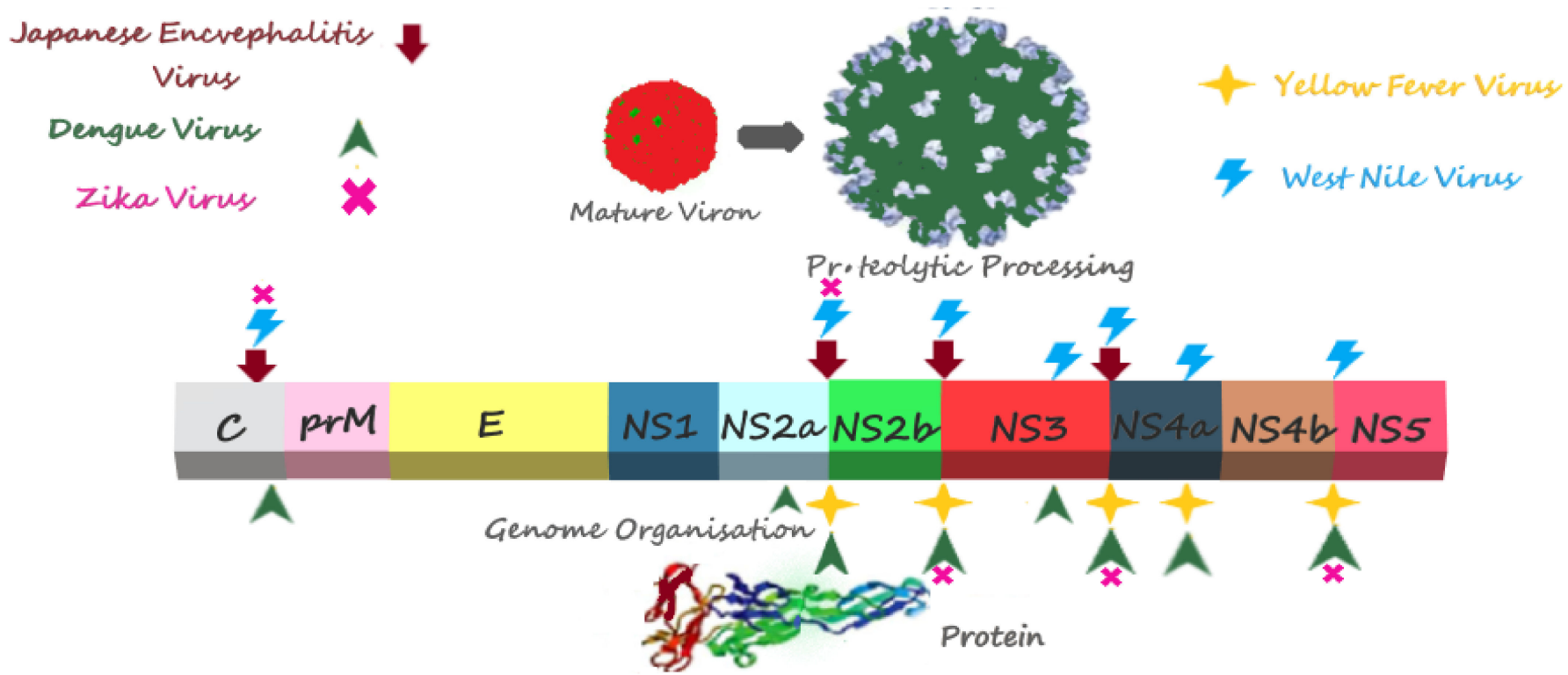

Figure 3. Cleavage sites proteolytically processed by NS2B-NS3 proteases in polyproteins of various flaviviruses: Cleavage sites proteolytically processed by Japanese encephalitis virus NS2B-NS3 proteases are shown by red arrows [32]; West Nile virus NS2B-NS3 cleavage sites are shown by blue lightning [67,118,122,123]; Yellow fever virus NS2B-NS3 cleavage sites are shown by yellow stars [69,70,124]; Dengue virus NS2B-NS3 cleavage sites are shown by green arrows [70,76,79,82,92,125,126]; and Zika virus NS2B-NS3 cleavage sites are shown by pink Xs [127].

\section{Interaction of Flavivirus NS2B-NS3 Proteases with Cellular Proteins}

The Flaviviral RNA tends to replicate on the membrane of the ER, leading to the formation of a replication complex. Many cellular and viral factors participate and are pivotal for the formation of this complex. Therefore, several NS proteins (including NS2B/NS3 
proteases) of the flaviviruses act together to retain the replication assembly at the ER. Owing to the larger genome of the DENV, extensive interactions are needed between DENV and the host cells. It has been reported that the NS3 protein of DENV redirects the fatty acid synthase (FASN) on the ER (the replication site for DENV). It was also seen that DENVinfected cells demonstrated the increased synthesis of the fatty acids during infection [128]. Moreover, it was also found that Rab 18 (GTPase located in the ER and that is responsible for vesicle trafficking) helps in the DENV replication by recruiting FASN to the sites where the virus is replicating, and by facilitating its interaction with NS3 to trigger fatty acid synthesis [129]. Recently, it has been reported that the NS3 of DENV (full-length isolated helical and protease domains of NS3) also interacts with the glyceraldehyde-3-phosphate dehydrogenase (GAPDH) enzyme, and this results in enhanced NS3 ATPase activity and reduced glycolytic activities [130]. The nonspecific functions of GAPDH are mRNA translation and stability [131,132]. Therefore, it may be postulated that the interaction between NS3 and GAPDH may result in the unwinding of double-stranded (ds) RNA, as well as vesicle formation (vesicle-induced), which is ultimately needed for virion assembly [130]. Recently, it has been found that the JEV NS3 protein also interacts with the isoforms of the 14-3-3 protein (14-3-3 $\varepsilon$ and 14-3-3 $\eta$ ) to block the translocation of the RIG-1 and MDA-5 from the cytosol to the mitochondria, thereby suppressing the host immune response, leading to enhanced viral replication in the cells. The researchers further postulated that the 14-3-3 protein is well conserved among insects, humans, and mice, and that targeting it may thereby facilitate viral replication in multiple hosts [133,134].

In order to maintain homeostasis, cells perform the process of reticulophagy (in which they degrade ER). FAM134B is one of the important host cell restriction factors located on the ER. A study has shown that the NS3 proteases of WNV, DENV, and ZIKV can cause the cleavage of FAM134B, thereby suppressing the reticulophagy pathway, leading to enhanced viral replication, presumably by utilizing the ER membrane for efficient viral budding [135]. The ZIKV NS2B/NS3 protease is also involved in interactions with many other cellular proteins, which include the cleavage of the cytoskeletal factor, Septin-2 (at residue R306), which results in slow cell division, enhanced apoptosis, multipolar spindles in the mitotic defects, and delayed cytokinesis in the neural progenitor cells (NPCs). These changes are likely to produce microencephalopathy [136]. Another study recently indicated that the DENV NS2B-NS3 protease is involved in the cleavage of the DDX21 protein. DDX21 is an RNA helicase enzyme that is involved in the host cell defense against a myriad of viral infections. In cells infected with DENV, there is a translocation of DDX21 from the nucleus to the cytosol. This causes the activation of IFN- $\beta$, and thus inhibits the DENV replication during early viral replication. Thus, DENV NS2B-NS3 proteases cause the subversion of the host cell immune system in order to facilitate enhanced viral replication [137]. While the interactions of NS3 with many cellular target proteins result in enhanced viral replication, many other proteins interact with the virus in a way that results in reduced viral replication. A heat shock protein, (Hsp 40) DNAJB6, interacted with NS3, which resulted in reduced viral propagation [138].

Mitochondria and mitochondrial-associated membranes (MAMs) are also known to play an important role in several processes that are pivotal for viral replication, i.e., ATP generation, lipid synthesis, and the induction of cellular apoptosis [139]. Flaviviruses also interact with mitochondria and MAMs and can regulate (up or down) these processes, causing the disturbance in cellular homeostasis. A recent study has demonstrated that the DENV NS2B3 protease interacts with mitochondria and results in the cleavage of MAMs and microfusion (MFN1 and 2) that ultimately leads to the fragmentation of the mitochondria, which can contribute to disease pathogenesis [140]. Keeping this in view, another study was designed to investigate the NS3 protease location in mitochondria. It was found that the N-terminal of the NS3 protease bears a mitochondrial signal sequence, and this facilitates its localization in the matrix of the mitochondria. Upon viral entry into the mitochondria, it was found that the NS3 pro and NS3 pro helicases both resulted in the cleavage of the GrpEL1 protein; the finding was also observed in the samples of 
clinically infected patients. GrpEL1 protein functions as a cochaperon of the Hsp-70 protein, which implies that the cleavage of the GrpEL1 protein may lead to the dysfunction of the Hsp-70 protein. The exact consequences of this dysfunction are yet to be elucidated; however, based on the correlation between the cellular level of the GrpEL1 protein and the platelet count, the possible dysfunction of the mitochondria was postulated, which leads to thrombocytopenia [141].

\section{Interactions of Flavivirus NS3 with Host Cell NPC and Nucleus}

The majority of macromolecular transport between the nucleus and the cytoplasm is mediated mainly through the nuclear pore complex (NPC). The NPC is a disk-like structure $(500 \mathrm{~nm} \times 100 \mathrm{~nm})$ that consists of multiple copies of 30 different proteins, which are termed "nucleoporins" (Nups). The NPC and its associated machinery play a pivotal role in the regulation of many cellular pathways. Different viruses have evolved a variety of strategies in order to manipulate the NPC in such a way that ultimately leads to the favoring of viral replication in cells [142]. Altering the NPC integrity is also one of the major activities carried out by viral-encoded proteases to facilitate the viral entry into the nucleus, thus favoring viral replication. This phenomenon has not only been observed in viruses replicating in the nucleus, but also in viruses that replicate in the cytoplasm. The flaviviral proteins are known to interact with the NPC and the associated proteins to disrupt the nucleocytoplasmic trafficking, and to gain entry into the nucleus [139]. The latter strategy may be adopted so that the NPC changes result in the reduced trafficking of mRNA or other transcription factors, which can result in a suppressed immune response against that viral infection [143]. Recent studies have also demonstrated the ability of flaviviral NS2B-NS3 to affect the integrity and distribution of nucleoporins (Nups). Nup62, Nup98, and Nup153 have been found to be disrupted by DENV, whereas Nup98 and Nup153 were affected by the ZIKV NS2B-NS3 proteases [144]. These studies indicate that the NPC and the associated factors in host cells are manipulated as the targets for Flaviviridae replication.

The NS3 of ZIKV tends to locate itself in the perinuclear regions of the infected cells, and causes alterations in the nuclear lamina structure, which leads to the formation of extrusion sites. This may affect the function of centromeres [145]. It has also been observed that NS3 tends to deposit itself on the concave surface of the nucleus (kidneyshaped altered nuclei) and may also be involved in changing the other components of the nuclear envelope [146]. Other studies have indicated that the NS3 of DENV is located on the nucleus of infected cells at an earlier time (8-12 h) than on cytoplasm (16-24 h), postinfection $[147,148]$.

\section{Characterization of Flavivirus NS2B-NS3 Proteases}

In order to design an appropriate flavivirus inhibitor, the very first approach is to design an appropriate substrate and optimize the in vitro reaction/working conditions for viral NS2B/NS3 proteases. Various substrate profiling studies have shown that the WNV protease preferentially cleaves at the $\mathrm{K} / \mathrm{R}$ motifs. The presence of bulky residues, e.g., Tyr, Trp, or Phe at positions P1 or P2, can be well tolerated by the DENV protease as long as the Gly occupies the other position [108,149]. The sequences of amino acid required for polyprotein processing in DENV, WNV, and YFV are homologues; however, minor differences exist among them. In DENV, the hydrolysis sites exist after a pair of basic residues, e.g., Lys-Arg, Arg-Arg, or Arg-Lys at positions P1 and P2 [69]. In WNV, the majority of cleavage sites possess Lys and Arg sequences at positions P2 and P1, and Gly at $\mathrm{P}^{\prime}$ [150]. Importantly, the YFV polyprotein processing sites contain a pair of Arg-Arg, followed by Gly, Val, or Ser [89]. The substrate sites/sequences susceptible to cleaving by various flavivirus NS2B-NS3 proteases are summarized in Table 1. 
Table 1. Cleavage sites from various flaviviruses: Arrowheads indicate the NS2B-NS3 proteasesusceptible cleavage positions in the polyproteins of various flaviviruses.

\begin{tabular}{|c|c|c|c|c|c|c|}
\hline \multirow{2}{*}{ Flavivirus } & \multicolumn{5}{|c|}{ Cleavage/Substrate Sites } & \multirow{2}{*}{ Reference } \\
\hline & Capsid C & NS2A/NS2B & NS2B/NS3 & NS3/NS4A & NS4B/NS5 & \\
\hline \multirow{3}{*}{ JEV } & VNKRGRKQNKRJ & NPNKKR & LKTTKR & FAAGKR & KPSLKR & \multirow{2}{*}{ [151] } \\
\hline & $\downarrow$ GGNEGS & $\downarrow$ GWPATE & $\downarrow$ GGVFWD & $\downarrow$ SAISFI & $\downarrow$ GRPGGR & \\
\hline & $\begin{array}{l}\text { NKRGRKQNKR } \\
\downarrow G G N E G S I M W L\end{array}$ & $\begin{array}{l}\text { GLMVCNPNKKR } \\
\downarrow \text { GWPAT EFLSA }\end{array}$ & $\begin{array}{l}\text { GYWLTLKTTKR } \\
\text { LGGVFWDTPSP }\end{array}$ & $\begin{array}{l}\text { WFKDFAAGKR } \\
\text { \SAVSFIEVLG }\end{array}$ & - & [32] \\
\hline \multirow[b]{2}{*}{ YFV } & LSSRKRR & RIFGRR & VRGARR & FAEGRR & MKTGRR & \multirow[b]{2}{*}{ [152] } \\
\hline & $\downarrow$ SHDVLT & $\downarrow S I P V N E$ & $\downarrow$ SGDVLM & $\downarrow$ GAAEVL & $\downarrow$ GSANGK & \\
\hline \multirow{4}{*}{ WNV } & INBBSTKQKKS & OPNRKR & LQYTKR & FASGKR & KPGLKR & \multirow{2}{*}{ [153-156] } \\
\hline & $\downarrow$ GGTAGF & $\downarrow$ GWPATE & $\downarrow$ GGVLWD & $\downarrow$ SQIGLV & $\downarrow$ GGAKGR & \\
\hline & & DPNRKR & LQYTKR & FASGKR & KPGLKR & \\
\hline & - & $\downarrow G W$ & $\downarrow G G$ & $\downarrow S Q$ & $\downarrow G G$ & [122] \\
\hline \multirow{2}{*}{ ZIKV } & KERKRR & TRSGKR & VKTGKR & FAAGKR & GLVKRR & \multirow{2}{*}[127,157]{} \\
\hline & $\downarrow$ GADTSIGI & $\downarrow$ SWPPSEVL & $\downarrow$ SGALWDVP & $\downarrow$ GAALGVME & $\downarrow$ GGGTGETL & \\
\hline DENV1 & MNRRKR & _- & _- & _- & $\ldots$ & [158] \\
\hline & $\downarrow$ SVTMLL & - & - & - & & \\
\hline \multirow{2}{*}{ DENV2 } & LNRRRR & RTSKKR & EVKKQR & FAAGRK & \multirow{2}{*}{-} & \multirow{2}{*}{ [159] } \\
\hline & $\downarrow$ TAGMII & $\downarrow$ SWPLNE & $\downarrow A G V L W D$ & $\downarrow$ SLTLNL & & \\
\hline DENV3 & $\begin{array}{l}\text { INKRKK } \\
\downarrow \text { TSLCLM }\end{array}$ & - & - & - & - & [160] \\
\hline \multirow[b]{2}{*}{ DENV4 } & LNGRKR & KGASRR & QVKTQR & FASGRK & AOTPRR & \multirow[b]{2}{*}[161,162]{} \\
\hline & $\downarrow$ STITLL & $\downarrow$ SWPLNE & $\downarrow S G A L W D$ & $\downarrow$ SITLDI & $\downarrow$ GTGTTG & \\
\hline
\end{tabular}

The $\mathrm{pH}$, the buffers, and the reaction temperature are crucial to characterizing flaviviral NS2B/NS3 proteases [76,77]. Several researchers have optimized these conditions to efficiently determine the in vitro proteolytic activities of NS2B-NS3 proteases, which are compiled in Table 2.

Table 2. In vitro reaction conditions for the optimum proteolytic activities of various flavivirus NS2B-NS3 proteases.

\begin{tabular}{|c|c|c|c|c|c|c|}
\hline \multirow{2}{*}{ Flavivirus } & \multicolumn{5}{|c|}{ Optimum Buffers and Reaction Conditions } & \multirow{2}{*}{ Reference } \\
\hline & Tris-HCl & $\mathrm{NaCl}$ & Glycerol & Temp & $\mathrm{pH}$ & \\
\hline DENV & $50 \mathrm{mM}$ & $50 \mathrm{mM}$ & $35 \%$ & $37^{\circ} \mathrm{C}$ & 8.5 & [67] \\
\hline JEV & $50 \mathrm{mM}$ & $25 \mathrm{mM}$ & $30 \%$ & $37^{\circ} \mathrm{C}$ & 9.5 & [75] \\
\hline WNV & $200 \mathrm{mM}$ & $13.5 \mathrm{mM}$ & $30 \%$ & $37^{\circ} \mathrm{C}$ & 9.5 & [163] \\
\hline \multirow[t]{2}{*}{ ZIKV } & 20 or $50 \mathrm{mM}$ & $150 \mathrm{mM}$ & 10 or $20 \%$ & $37^{\circ} \mathrm{C}$ & 8.5 & {$[50,164,165]$} \\
\hline & Tris-HCl & Acetic Acid & Glycine & Temp & $\mathrm{pH}$ & \\
\hline YFV & $75 \mathrm{mM}$ & $25 \mathrm{mM}$ & $25 \mathrm{mM}$ & $37^{\circ} \mathrm{C}$ & 7.0 & [166] \\
\hline
\end{tabular}

\section{NS2B-NS3 Proteases as a Potential Viral Inhibition Drug Target}

Flavivirus two-component nonstructural NS2B-NS3 proteases are essential for the viral life cycle and, consequently, are a promising drug target. Using NS2B-NS3 proteases is one of the major antiviral strategies for researchers. Just as in HIV and HCV, protease offers a unique target for the inhibition of viral replication by employing a variety of peptides and pseudopeptides [167]. Substrates with di- or polybasic recognition sequences exhibit a strong affinity for viral protease. This recognition tends to be conserved among various Flaviviruses and, therefore, it may be employed as a promising antiviral target with a relatively broad spectrum [61]. The shallowness of the substrate-binding pocket, and its exposure to the solvents, make the interaction of the protease and the peptidomimetics labile. Moreover, the stability and permeability of the peptidomimetics are further hindered by the polybasic residues at P1 and P2. The other possible strategy may disrupt the interaction between the NS2B and NS3 domains [168]. Numerous studies have employed the in silico (molecular docking) approach or have used high-throughput chemical screening for the discovery of novel NS2B-NS3 protease inhibitors $[169,170]$. Moreover, substrates having fluorogenic 
peptides have also been used for the discovery of novel NS2B-NS3 proteases inhibitors. The active protease was produced in a bacterial expression system, and the enzyme's specificity for synthesized FRET-type substrate libraries was profiled [171]. These protease inhibitors may be categorized as peptides and are also known as "peptidomimetics" (substratederived) or "small molecules" (not substrate-derived). Peptides/peptidomimetics exhibit high affinities and minimal drug-like molecules, whereas the latter ones act in a reverse manner, i.e., they have less affinity and are more drug-like. The desirable lower nanomolar range of the dissociation constants (in association with protease) is only exhibited by very few inhibitors, and a majority of them are peptide-based substrate mimetics [172-176]. Numerous antivirals have been screened against flaviviruses targeting recombinant viral proteases, the details of which are provided in Table 3.

Table 3. Antivirals and their mechanisms screened by targeting flavivirus two-component NS2BNS3 proteases.

\begin{tabular}{|c|c|c|c|c|}
\hline Sr No & Flavivirus & $\begin{array}{c}\text { Antivirals Screened by Targeting NS2B/NS3 } \\
\text { Proteases }\end{array}$ & Mechanism & Reference \\
\hline \multirow{16}{*}{1} & \multirow{16}{*}{$\begin{array}{c}\text { WNV } \\
\text { (West Nile } \\
\text { Virus) }\end{array}$} & $\begin{array}{l}\text { Benzoyl-norleucine-lysine-arginine-arginine } \\
\text { (Bz-nKRR) tetrapeptide aldehyde }\end{array}$ & \multirow{3}{*}{$\begin{array}{l}\text { C-terminal electrophile } \\
\text { incorporation }\end{array}$} & [177] \\
\hline & & Cationic tripeptides (along with nonpeptide cap) & & [176] \\
\hline & & Peptide-boronic acid inhibitors & & [173] \\
\hline & & Benzyl ethers of 4-hydroxyphenylglycine & \multirow{3}{*}{$\begin{array}{l}\text { N-terminal capping moiety } \\
\text { optimization }\end{array}$} & [172] \\
\hline & & Bz-Arg-Lys-X-NH & & [178] \\
\hline & & $\begin{array}{l}\text { Peptide-hybrids based on 2,4-thiazolidinedione } \\
\text { scaffolds containing nonpolar groups }\end{array}$ & & [179] \\
\hline & & Benzyl ethers of 4-hydroxyphenylglycine & $\begin{array}{l}\text { P1 and P2 basic residue } \\
\text { modulation }\end{array}$ & [172] \\
\hline & & Aprotinin & \multirow{2}{*}{ Noncompetitive inhibitors } & [117] \\
\hline & & Palmatine (Coptis chinensis) & & [180] \\
\hline & & $\begin{array}{l}\text { Derivatives of Guanidinylated } \\
\text { 2,5-dideoxystreptamine }\end{array}$ & Competitive inhibitors & [181] \\
\hline & & $\begin{array}{l}\text { Benzoyl-norleucine-lysine-arginine- arginine } \\
\text { (Bz-nKRR) tetrapeptide aldehyde }\end{array}$ & \multirow[t]{2}{*}{ Aldehydic inhibitors } & [177] \\
\hline & & Cationic tripeptides (along with nonpeptide cap) & & {$[176]$} \\
\hline & & Aprotinin & Stearic hindrance of active site & [175] \\
\hline & & D-arginine-based 9-12-mer peptides & \multirow{2}{*}{$\begin{array}{l}\text { Mechanism yet to be } \\
\text { determined }\end{array}$} & [175] \\
\hline & & Furin & & [182] \\
\hline & & C-Terminal Electrophile incorporation & Peptide-boronic acid inhibitors & [173] \\
\hline
\end{tabular}


Table 3. Cont.

\begin{tabular}{|c|c|c|c|c|}
\hline Sr No & Flavivirus & $\begin{array}{c}\text { Antivirals Screened by Targeting NS2B/NS3 } \\
\text { Proteases }\end{array}$ & Mechanism & Reference \\
\hline \multirow{24}{*}{2} & \multirow{24}{*}{$\begin{array}{c}\text { DENV } \\
\text { (Dengue Virus) }\end{array}$} & $\begin{array}{c}\text { Tetrapeptide: } \\
\text { Bz-Nle-Lys-Arg-Arg-B(OH)2 (boronic acid } \\
\text { analogue) }\end{array}$ & $\begin{array}{l}\text { C-Terminal electrophile } \\
\text { incorporation }\end{array}$ & [170] \\
\hline & & Benzyl ethers of 4-hydroxyphenylglycine & optimization & [172] \\
\hline & & Bz-Arg-Lys-X-NH & N-terminal capping moiety & [178] \\
\hline & & Rhodanines and Thiazolidinediones & $\begin{array}{l}\text { optimization } \\
\text { P1 and P2 hasic residue }\end{array}$ & [183] \\
\hline & & Benzyl ethers of 4-hydroxyphenylglycine & modulation & [172] \\
\hline & & Plectasin & Noncompetitive inhibition & [184] \\
\hline & & $\begin{array}{c}\text { Substitution of Arg with unnatural Arg motifs in } \\
\text { the P2 }\end{array}$ & $\mathrm{P} 1$ and $\mathrm{P} 2$ basic residue & [185] \\
\hline & & $\begin{array}{l}\text { Benzoyl-norleucine-lysine-arginine- arginine } \\
\text { (Bz-nKRR) tetrapeptide aldehyde }\end{array}$ & $\begin{array}{l}\text { Aldehydic inhibitors(against } \\
\text { DENV 2) }\end{array}$ & [177] \\
\hline & & Cationic tripeptides (along with nonpeptide cap) & $\begin{array}{l}\text { Aldehydic inhibitors (against } \\
\text { DENV 2) }\end{array}$ & [176] \\
\hline & & Cyclopentapeptide (CKRKC) & \multirow{11}{*}{ Mechanism yet to be determined } & [186] \\
\hline & & BP-2109 & & [187] \\
\hline & & BP13944 & & [188] \\
\hline & & BT 24 (quinoline compound) & & [189] \\
\hline & & Aminobenzamide & & [190] \\
\hline & & 2,5,6-trisubstituted pyrazine compounds & & [191] \\
\hline & & Furin & & [182] \\
\hline & & Protegrin-1 & & [192] \\
\hline & & Retrocyclin-1 & & [193] \\
\hline & & Chalcone derivatives (DENV-2) & & [194] \\
\hline & & $\begin{array}{l}\text { Flavonoids (fingerroot) } \\
\quad \text { (DENV-2) }\end{array}$ & & [194] \\
\hline & & Tyrothricin & \multirow{2}{*}{ Competitive inhibition } & [195] \\
\hline & & $\begin{array}{l}\text { Derivatives of Guanidinylated } \\
\text { 2,5-dideoxystreptamine }\end{array}$ & & [181] \\
\hline & & $\begin{array}{c}\text { Retrotripeptides: } \\
\text { R-Arg-Lys-Nle-NH2 } \\
\text { Ivermectin } \\
\text { Selamectin } \\
\text { Benezethonium chloride }\end{array}$ & Mixed inhibition & $\begin{array}{l}{[196]} \\
{[195]}\end{array}$ \\
\hline & & Peptide-boronic acid & $\begin{array}{l}\text { C-terminal electrophile } \\
\text { incorporation }\end{array}$ & [173] \\
\hline
\end{tabular}


Table 3. Cont.

\begin{tabular}{|c|c|c|c|c|}
\hline $\begin{array}{l}\text { Sr } \\
\text { No }\end{array}$ & Flavivirus & $\begin{array}{c}\text { Antivirals Screened by Targeting NS2B/NS3 } \\
\text { Proteases }\end{array}$ & Mechanism & Reference \\
\hline \multirow{9}{*}{3} & \multirow{9}{*}{$\begin{array}{c}\text { ZIKV } \\
\text { (Zika Virus) }\end{array}$} & Peptidomimetic boronic acid & $\begin{array}{l}\text { Formation of salt bridge with } \\
\text { Asp83 of NS2B }\end{array}$ & [95] \\
\hline & & Bromocriptine & \multirow{8}{*}{ Mechanism yet to be determined } & [197] \\
\hline & & Novobiocin & & [198] \\
\hline & & Hydroxychloroquine & & [199] \\
\hline & & Erythrosin B & & [200] \\
\hline & & Theaflavin- $3,3^{\prime}$-digallate & & [201] \\
\hline & & 9b (HIV protease inhibitor) & & [202] \\
\hline & & 2,5,6-trisubstituted pyrazine compounds & & [191] \\
\hline & & Aprotinin & & [75] \\
\hline 4 & $\begin{array}{c}\text { JEV } \\
\text { (Japanese } \\
\text { Encephalitis Virus) }\end{array}$ & NSC135618 & $\begin{array}{c}\text { Inhibits the conformational } \\
\text { change of NS2B (allosteric } \\
\text { inhibitor) }\end{array}$ & [203] \\
\hline 5 & $\begin{array}{c}\text { YFV } \\
\text { (Yellow fever Virus) }\end{array}$ & Erythrosin B & Mechanism yet to be determined & [200] \\
\hline
\end{tabular}

13. Proposing Role of STING in Development of In Vitro and In Vivo Models for Studying Flavivirus Pathogenesis and Antiviral Drug Screens

One of the major strategies used to develop a vaccine or antiviral drug against flavivirus is through studying disease by employing animal models (Table 4). However, it is difficult to use such models to study flaviviral pathogenesis and disease control measures. For instance, various studies have reported using humanized mice for studying the clinical infection of DENV, with several limitations associated with their use [204-212]. There is also a paucity of information on using them to successfully test DENV and ZIKV vaccines [213]. The lack of animal models against flaviviruses has hampered a deep understanding and the development of novel therapeutics/vaccines against most of the flaviviruses. To be used for vaccine or novel therapeutic testing, animal models must exhibit immune competency and viremia (reproducible) against the virus. Moreover, it is also required that the animal model inoculated with a particular virus must demonstrate the same signs as in natural infection. For example, in the case of DENV, none of the humanized mice exhibited the classical features of hemorrhage and the leakage of plasma [214]. That is why a combination of several different models is needed to test the therapeutic efficacy of a novel antiviral or vaccine candidate against different flaviviruses.

Finding a cellular protein that acts particularly as a substrate for some enzymes greatly increases the mechanistic specificity for that protein. Studies in the past have demonstrated a potential new cellular target, the STING (the stimulator of interferon gene) protein, which may allow researchers to develop some appropriate animal models to design novel therapeutics against flavivirus NS2B-NS3, as it has been found that all flavivirus NS2B-NS3 (except YFV) preferentially cleaves to the STING as a substrate [215].

The STING is a multipass protein that resides on the ER, and it plays a pivotal role in inducing the innate immune signaling upon intracellular infection [216-219]. Originally, it was proposed that it is activated on the intracellular binding of cytosolic DNA species, such as viral DNA, [217,220]. However, later studies have demonstrated that it may also be activated by viral RNA infection [221]. Because of its important role in innate immunity and interferon (IFN) production, several viruses possess proteins that can degrade the STING [215,222-225]. The NS2B-NS3 proteases of flaviviruses (WNV, ZIKV, JEV, and DENV; but not YFV), for instance, effectively cleave the STING in human cells, leading to the lower production of type I IFN by those cells, resulting in enhanced intracellular viral 
replication [215,222,225,226]. Moreover, DENV is also known to play a critical role in the degradation of STAT2, another player in the host immune response [227-230]. However, the mice STING is resistant to degradation by flavivirus proteins, which results in strong interferon responses and protects them from flavivirus infection [222,225,227,231]. For this reason, they are unable to be used as an effective model for experimental flavivirus infection.

Table 4. Animals and cellular models for studying Flavivirus pathogenesis/vaccine development.

\begin{tabular}{|c|c|c|c|}
\hline \multicolumn{4}{|c|}{ Animal Models for Studying Dengue Virus (DENV) } \\
\hline Animal Type & Model & Study Conducted/Findings & Reference \\
\hline \multirow{16}{*}{$\begin{array}{l}\text { Nonhuman } \\
\text { Primates }\end{array}$} & \multirow{9}{*}{ Rhesus macaquesa } & Inactivated vaccine (DENV-II). & {$[232]$} \\
\hline & & Expression of G protein in Vaccinia virus (DENV-2). & {$[233]$} \\
\hline & & DNA vaccine (encoding Pr-M and E) of DENV-2. & [234] \\
\hline & & DENV-I vaccine. & [235] \\
\hline & & Tetravalent vaccine expressed in Adenovirus. & {$[236]$} \\
\hline & & Tetravalent DNA vaccine (chimeric). & [237] \\
\hline & & Mutant DENV (live attenuated) vaccine. & [238] \\
\hline & & Inactivated DENV (tetravalent). & [239] \\
\hline & & DNA vaccine. & [240] \\
\hline & \multirow{7}{*}{ Cynomolgous macaques } & Live attenuated and recombinant vaccine comparison. & [241] \\
\hline & & Chimeric DENV1/2 vaccine. & [242] \\
\hline & & Recombinant DENV. & [243] \\
\hline & & Recombinant protein (DENV 1-4). & [244] \\
\hline & & Tetravalent DENV vaccine (chimeric). & [245] \\
\hline & & Tetravalent DENV vaccine (live attenuated). & [246] \\
\hline & & DENV-2 virus-like particles. & [247] \\
\hline \multirow{11}{*}{ Mice } & $\mathrm{A} / \mathrm{J}$ & DENV-2 caused thrombocytopenia. & {$[248]$} \\
\hline & \multirow{3}{*}{$\begin{array}{l}\text { AG129 (do not have type I and II } \\
\text { Interferon receptors) }\end{array}$} & DENV caused neurological manifestations leading to death. & [249] \\
\hline & & $\begin{array}{l}\text { DENV infection caused systemic infection and vascular leakage, leading } \\
\text { to death. }\end{array}$ & {$[250]$} \\
\hline & & DENV infection resulted in splenomegaly. & [251] \\
\hline & $\begin{array}{l}\text { IFNAR }-/- \text { (Lack of IFN type I } \\
\text { receptors; background of C57BL/6 } \\
\text { mice) }\end{array}$ & $\begin{array}{l}\text { DENV-2 infection resulted in viral growth in small intestine, liver, and } \\
\text { bone marrow, resulting in death. }\end{array}$ & [252] \\
\hline & Cardif $-/-$ & $\begin{array}{l}\text { DENV infection in mice resulted in viral growth in lymph nodes, bone } \\
\text { marrow, and spleen. }\end{array}$ & [253] \\
\hline & STAT $1-/-$ & $\begin{array}{c}\text { DENV infection resulted in viral growth in kidney, liver, and small } \\
\text { intestine; however, the mice survived. }\end{array}$ & \multirow{5}{*}[254]{} \\
\hline & STAT $2-/-$ & $\begin{array}{c}\text { DENV infection resulted in viral growth in kidney, liver, and small } \\
\text { intestine; however, the mice survived. }\end{array}$ & \\
\hline & $\begin{array}{l}\text { STAT } 1-/- \text { STAT } 2-/- \\
\text { (Lack STAT } 1 \text { and } 2 \text { proteins) }\end{array}$ & $\begin{array}{l}\text { DENV infection resulted in higher viral titers in serum, kidney, liver, } \\
\text { small intestine, and spleen, and mice death occurred. }\end{array}$ & \\
\hline & $\begin{array}{c}\text { STAT1 }-/-/ \\
\text { IFNAR }-/- \\
\text { (Lack of STAT1 and type I IFN } \\
\text { receptor) }\end{array}$ & $\begin{array}{l}\text { DENV infection resulted in higher viral titers in serum, kidney, liver, } \\
\text { small intestine, and spleen, and mice death occurred. }\end{array}$ & \\
\hline & $\begin{array}{c}\text { STAT1 }-/-/ \\
\text { IFNGR }-/- \text { (Lack of STAT1 and type } \\
\text { II IFN receptor) }\end{array}$ & Mice survived & \\
\hline
\end{tabular}


Table 4. Cont.

\begin{tabular}{|c|c|c|c|c|c|}
\hline \multicolumn{6}{|c|}{ Animal Models for Studying Yellow Fever Virus (YFV) } \\
\hline $\begin{array}{l}\text { Animal } \\
\text { Type }\end{array}$ & Model & \multicolumn{3}{|c|}{ Study Conducted/Findings } & Reference \\
\hline \multirow{2}{*}{$\begin{array}{l}\text { Nonhuman } \\
\text { Primates }\end{array}$} & \multirow{2}{*}{$\begin{array}{l}\text { Cynomolgous } \\
\text { macaques }\end{array}$} & \multicolumn{3}{|c|}{ YFV-DENV(1-4) vaccine } & {$[255]$} \\
\hline & & \multicolumn{3}{|c|}{ YFV-DENV Chimeric vaccine } & {$[256]$} \\
\hline \multicolumn{6}{|c|}{ Models for Studying Flavivirus NS2B-NS3 Proteases } \\
\hline \multicolumn{2}{|c|}{ Virus Type } & Cells & Animal Spp. & Outcome & Reference \\
\hline \multirow{4}{*}{\multicolumn{2}{|c|}{$\begin{array}{l}\text { DENV } \\
\text { ZIKV } \\
\text { JEV } \\
\text { WNV }\end{array}$}} & \multirow{4}{*}{$\begin{array}{l}\text { Dermal } \\
\text { fibroblasts (DFs) }\end{array}$} & $\begin{array}{c}\text { Great apes (Pan paniscus, Pan } \\
\text { troglodytes, Pongo pygmaeus } \\
\text { Gorilla gorilla) }\end{array}$ & $\begin{array}{c}\text { Dermal fibroblasts (DFs) } \\
\text { demonstrated increased mice } \\
\text { susceptibility to infection by } \\
\text { Flaviviruses. }\end{array}$ & \multirow{4}{*}[215]{} \\
\hline & & & $\begin{array}{c}\text { Old World monkeys (Macaca } \\
\text { nemestrina, Papio anubis, } \\
\text { Macaca mulatta) }\end{array}$ & $\begin{array}{l}\text { Increased mice susceptibility } \\
\text { to infection by Flaviviruses. }\end{array}$ & \\
\hline & & & $\begin{array}{l}\text { New world monkeys (Saimiri } \\
\text { sciureus) }\end{array}$ & $\begin{array}{l}\text { Increased mice susceptibility } \\
\text { to infection by Flaviviruses. }\end{array}$ & \\
\hline & & & Mice (Tmem173Gt) & $\begin{array}{l}\text { STING disruption increased } \\
\text { mice susceptibility to } \\
\text { infection by Flaviviruses; } \\
\text { however, they could not } \\
\text { develop serious infection } \\
\text { (underlines the role of } \\
\text { redundant pathways in viral } \\
\text { replication dynamics). }\end{array}$ & \\
\hline
\end{tabular}

In order to study the flavivirus NS2B-NS3 proteases in vitro, it is very important to develop cellular models that have functional STINGs that may be cleaved by flavivirus NS2B-NS3 proteases, as it occurs under clinical circumstances in humans. A variety of cells from the human lineage may be used for this purpose. A recently conducted study on ZIKV demonstrated the ability of ZIKV-associated NS2B-NS3 proteases to cleave the STING in fibroblasts derived from humans, as well as nonhuman primates (NHPs) [215]. The results from this study make it possible to use NHP-derived fibroblasts as a possible cell-based model to study and develop novel antiviral drugs/vaccines against flavivirus NS2B-NS3 proteases in vitro.

Similarly, in most of the NHPs, DENV cannot degrade the STING because of a small variation in the STING sequence of nonhuman primates [226]. This small variation may demonstrate the reason for better DENV replication in humans. Further studies have shown that the STING can effectively be degraded in three species of rodents and apes, each indicating the possibility of using these species as an effective model of flavivirus replication in the nonhuman host [226]. The results of this study are promising and provide new hope for the use of these animal hosts as models for studying pathogenesis, and for designing novel therapeutic products against flavivirus NS2B-NS3 proteases.

Moreover, testing drugs on animals prior to humans is one of the preliminary requirements. The abovementioned studies may also pave the path towards finding a possible use for NHPs as animal models for studying the pathogenesis of different flaviviruses. Therefore, in the future, different NHPs (Old and New World monkeys, great apes) may be tested for different flavivirus replications, thus allowing for the use of in vivo models for flavivirus replication, understanding pathogenesis, and devising novel antiviral treatments.

\section{Conclusions}

In this review, the structure, optimized reaction/working conditions, potential antiviral targets, and possible cellular and animal models are proposed to study the NS2B-NS3 proteases of various flaviviruses. One approach to treat flavivirus infection is through developing enzyme inhibitors. This approach involves finding compounds that can interact 
and disorient the enzymatic active site in such a way that it is no longer capable of carrying out its specific function/reaction. Thus, this approach often serves as the starting point for selecting an antiviral inhibitor, whose binding affinity for the active site often resembles, or even exceeds, the normal substrate. Using this approach, many promising compounds have been discovered, as described previously. However, it is also important to mention here that, despite more than two decades of research, not much success has been observed in developing NS2B-NS3 protease inhibitors, and there are several reasons. Firstly, the flat and hydrophobic nature of the enzyme's active site greatly hinders the strong binding affinity of the inhibitor with its active site. Secondly, from a toxicological point of view, the structure of the active site of NS2B-NS3 proteases greatly resembles the host serine proteases, and, thus, the use of such NS2B-NS3 protease inhibitors may lead to severe damage in the host cells. Therefore, prolonged studies must be conducted at the cellular level and with experimental animals before its consideration for use in humans. Moreover, as the active site exhibits great affinity towards positively charged substrates/inhibitors, the use of such compounds may have some negative effects on the bioavailability of the compounds.

The latest crystallographic studies of NS2B-NS3 proteases with substrate-bound and unbound forms have provided some mechanistic evidence of the enzymatic mode of action, which may help in the future for developing a potential safe inhibitor of NS2B-NS3 proteases. Both in silico and high-throughput screening (HTS) methods may be deployed initially for shortlisting the inhibitors of NS2B-NS3 proteases, which may later be confirmed through crystallographic studies. These studies may help in identifying the more allosteric sites in flavivirus NS2B-NS3 proteases, and may lead to the discovery of more effective, potent, and safe flavivirus NS2B-NS3 protease inhibitors. Moreover, as the structures of NS2B-NS3 proteases exhibit great similarity in different flaviviruses, efforts must be made to find an antiviral agent that can be used effectively to inhibit proteases from different flaviviruses, and that thus exhibit a broad range of antiviral activities.

Author Contributions: Original draft preparation, visualization, data collection, A.W. and B.E.M.; data collection and validation, M.H., M.N.A. and K.L.; review, editing, and visualization, N.J.S., J.W. and Y.Q.; supervision, review, editing, and final draft preparation, J.W., Y.Q., A.W. and Z.M. All authors have read and agreed to the published version of the manuscript.

Funding: The study was supported by the National Key Research and Development Program of China (No. 2016YFD0500404), the Natural Science Foundation of Shanghai (No. 19ZR1469000), the Central Public-interest Scientific Institution Basal Research Fund (No. Y2020PT40), and Shanghai Science and Technology Development Funds (No. 17391901600).

Institutional Review Board Statement: Not applicable.

Informed Consent Statement: Not applicable.

Data Availability Statement: Not applicable.

Acknowledgments: We are very thankful to Maj A. Hannan, Rabia Khanum, and Xue Wang for their excellent moral support and for the fruitful discussions regarding this article.

Conflicts of Interest: The authors declare no conflict of interest.

\section{References}

1. Westaway, E.G.; Brinton, M.A.; Gaidamovich, S.Y.; Horzinek, M.C.; Igarashi, A.; Kääriäinen, L.; Lvov, D.K.; Porterfield, J.S.; Russell, P.K.; Trent, D.W. Flaviviridae. Intervirology 1985, 24, 183-192. [CrossRef] [PubMed]

2. Calisher, C.H.; Gould, E.A. Taxonomy of the virus family Flaviviridae. Adv. Virus Res. 2003, 59, 1-19. [PubMed]

3. Bessaud, M.; Pastorino, B.A.M.; Peyrefitte, C.N.; Rolland, D.; Grandadam, M.; Tolou, H.J. Functional characterization of the NS2B/NS3 protease complex from seven viruses belonging to different groups inside the genus Flavivirus. Virus Res. 2006, 120, 79-90. [CrossRef]

4. Mukhopadhyay, S.; Kuhn, R.J.; Rossmann, M.G. A structural perspective of the flavivirus life cycle. Nat. Rev. Microbiol. 2005, 3, 13-22. [CrossRef] [PubMed] 
5. Gyawali, N.; Taylor-Robinson, A.W.; Bradbury, R.S.; Potter, A.; Aaskov, J.G. Infection of Western Gray Kangaroos (Macropus fuliginosus) with Australian Arboviruses Associated with Human Infection. Vector-Borne Zoonotic Dis. 2020, 20, 33-39. [CrossRef] [PubMed]

6. Angsubhakorn, S.; Moe, J.B.; Latendresse, J.R.; Ward, G.S.; Ngamprochana, M.; Sahaphong, S.; Bhamarapravati, N. The neurovirulence of flaviviruses in crab-eating monkeys (Macaca fascicularis). S. Asian J. Trop. Med. Public Health 1986, 17, 604-612.

7. Valentine, M.J.; Murdock, C.C.; Kelly, P.J. Sylvatic cycles of arboviruses in non-human primates. Parasites Vectors 2019, $12,463$. [CrossRef] [PubMed]

8. Weissenböck, H.; Hubálek, Z.; Bakonyi, T.; Nowotny, N. Zoonotic mosquito-borne flaviviruses: Worldwide presence of agents with proven pathogenicity and potential candidates of future emerging diseases. Veter Microbiol. 2010, 140, 271-280. [CrossRef] [PubMed]

9. Nguyen-Tien, T.; Lundkvist, Å.; Lindahl, J. Urban transmission of mosquito-borne flaviviruses-A review of the risk for humans in Vietnam. Infect. Ecol. Epidemiol. 2019, 9, 1660129. [CrossRef]

10. Vasilakis, N.; Weaver, S.C. Flavivirus transmission focusing on Zika. Curr. Opin. Virol. 2017, 22, 30-35. [CrossRef] [PubMed]

11. Magalhaes, T.; Foy, B.D.; Marques, E.T.; Ebel, G.D.; Weger-Lucarelli, J. Mosquito-borne and sexual transmission of Zika virus: Recent developments and future directions. Virus Res. 2018, 254, 1-9. [CrossRef]

12. Pandit, P.S.; Doyle, M.M.; Smart, K.M.; Young, C.C.W.; Drape, G.W.; Johnson, C.K. Predicting wildlife reservoirs and global vulnerability to zoonotic Flaviviruses. Nat. Commun. 2018, 9, 5425. [CrossRef] [PubMed]

13. Blahove, M.R.; Carter, J.R. Flavivirus Persistence in Wildlife Populations. Viruses 2021, 13, 2099. [CrossRef] [PubMed]

14. Kuno, G. Host range specificity of flaviviruses: Correlation with in vitro replication. J. Med. Entomol. 2007, 44, 93-101. [CrossRef] [PubMed]

15. Migné, C.; Moutailler, S.; Attoui, H. Strategies for Assessing Arbovirus Genetic Variability in Vectors and/or Mammals. Pathogens 2020, 9, 915. [CrossRef] [PubMed]

16. Qiu, Y.; Xu, Y.-P.; Wang, M.; Miao, M.; Zhou, H.; Xu, J.; Kong, J.; Zheng, D.; Li, R.-T.; Zhang, R.-R.; et al. Flavivirus induces and antagonizes antiviral RNA interference in both mammals and mosquitoes. Sci. Adv. 2020, 6, eaax7989. [CrossRef] [PubMed]

17. Lannes, N.; Garcia-Nicolàs, O.; Démoulins, T.; Summerfield, A.; Filgueira, L. CX3CR1-CX3CL1-dependent cell-to-cell Japanese encephalitis virus transmission by human microglial cells. Sci. Rep. 2019, 9, 4833. [CrossRef] [PubMed]

18. Hameed, M.; Liu, K.; Anwar, N.; Wahaab, A.; Safdar, A.; Di, D.; Boruah, P.; Xu, J.; Wang, X.; Li, B.; et al. The emerged genotype I of Japanese encephalitis virus shows an infectivity similar to genotype III in Culex pipiens mosquitoes from China. PLoS Negl. Trop. Dis. 2019, 13, e0007716. [CrossRef] [PubMed]

19. Hameed, M.; Wahaab, A.; Shan, T.; Wang, X.; Khan, S.; Di, D.; Xiqian, L.; Zhang, J.-J.; Anwar, M.N.; Nawaz, M.; et al. A Metagenomic Analysis of Mosquito Virome Collected From Different Animal Farms at Yunnan-Myanmar Border of China. Front. Microbiol. 2021, 11, 591478. [CrossRef] [PubMed]

20. Daep, C.A.; Muñoz-Jordán, J.L.; Eugenin, E.A. Flaviviruses, an expanding threat in public health: Focus on dengue, West Nile, and Japanese encephalitis virus. J. Neurovirol. 2014, 20, 539-560. [CrossRef]

21. Kuno, G.; Chang, G.-J.J.; Tsuchiya, K.R.; Karabatsos, N.; Cropp, C.B. Phylogeny of the Genus Flavivirus. J. Virol. 1998, 72, 73-83. [CrossRef]

22. Leung, J.Y.; Pijlman, G.; Kondratieva, N.; Hyde, J.; Mackenzie, J.M.; Khromykh, A.A. Role of Nonstructural Protein NS2A in Flavivirus Assembly. J. Virol. 2008, 82, 4731-4741. [CrossRef] [PubMed]

23. Brand, C.; Bisaillon, M.; Geiss, B.J. Organization of the Flavivirus RNA replicase complex. Wiley Interdiscip. Rev. RNA 2017, 8 , e1437. [CrossRef] [PubMed]

24. Chambers, T.J.; Hahn, C.S.; Galler, R.; Rice, C.M. Flavivirus Genome Organization, Expression, and Replication. Ann. Rev. Microbiol. 1990, 44, 649-688. [CrossRef] [PubMed]

25. Li, H.; Clum, S.; You, S.; Ebner, K.E.; Padmanabhan, R. The Serine Protease and RNA-Stimulated Nucleoside Triphosphatase and RNA Helicase Functional Domains of Dengue Virus Type 2 NS3 Converge within a Region of 20 Amino Acids. J. Virol. 1999, 73, 3108-3116. [CrossRef] [PubMed]

26. Utama, A.; Shimizu, H.; Morikawa, S.; Hasebe, F.; Morita, K.; Igarashi, A.; Hatsu, M.; Takamizawa, K.; Miyamura, T. Identification and characterization of the RNA helicase activity of Japanese encephalitis virus NS3 protein. FEBS Lett. 2000, 465, 74-78. [CrossRef]

27. Preugschat, F.; Yao, C.W.; Strauss, J.H. In vitro processing of dengue virus type 2 nonstructural proteins NS2A, NS2B, and NS3. J. Virol. 1990, 64, 4364-4374. [CrossRef]

28. Wengler, G.; Wengler, G. The NS 3 nonstructural protein of flaviviruses contains an RNA triphosphatase activity. Virology 1993, 197, 265-273. [CrossRef]

29. Takegami, T.; Sakamuro, D.; Furukawa, T. Japanese encephalitis virus nonstructural protein NS3 has RNA binding and ATPase activities. Virus Genes 1995, 9, 105-112. [CrossRef]

30. Wengler, G.; Czaya, G.; Färber, P.M.; Hegemann, J.H. In vitro synthesis of West Nile virus proteins indicates that the aminoterminal segment of the NS3 protein contains the active centre of the protease which cleaves the viral polyprotein after multiple basic amino acids. J. General Virol. 1991, 72 Pt 4, 851-858. [CrossRef]

31. Warrener, P.; Tamura, J.K.; Collett, M.S. RNA-stimulated NTPase activity associated with yellow fever virus NS3 protein expressed in bacteria. J. Virol. 1993, 67, 989-996. [CrossRef] [PubMed] 
32. Wahaab, A.; Liu, K.; Hameed, M.; Anwar, M.; Kang, L.; Li, C.; Ma, X.; Wajid, A.; Yang, Y.; Khan, U.; et al. Identification of Cleavage Sites Proteolytically Processed by NS2B-NS3 Protease in Polyprotein of Japanese Encephalitis Virus. Pathogens 2021, 10, 102. [CrossRef] [PubMed]

33. Guyatt, K.J.; Westaway, E.G.; Khromykh, A.A. Expression and purification of enzymatically active recombinant RNA-dependent RNA polymerase (NS5) of the flavivirus Kunjin. J. Virol. Methods 2001, 92, 37-44. [CrossRef]

34. Tan, B.H.; Fu, J.; Sugrue, R.J.; Yap, E.H.; Chan, Y.C.; Tan, Y.H. Recombinant dengue type 1 virus NS5 protein expressed in Escherichia coli exhibits RNA-dependent RNA polymerase activity. Virology 1996, 216, 317-325. [CrossRef]

35. Egloff, M.; Benarroch, D.; Selisko, B.; Romette, J.; Canard, B. An RNA cap (nucleoside-2'-O-)-methyltransferase in the flavivirus RNA polymerase NS5: Crystal structure and functional characterization. EMBO J. 2002, 21, 2757-2768. [CrossRef] [PubMed]

36. Issur, M.; Geiss, B.J.; Bougie, I.; Picard-Jean, F.; Despins, S.; Mayette, J.; Hobdey, S.E.; Bisaillon, M. The flavivirus NS5 protein is a true RNA guanylyltransferase that catalyzes a two-step reaction to form the RNA cap structure. RNA 2009, 15, 2340-2350. [CrossRef]

37. Ray, D.; Shah, A.; Tilgner, M.; Guo, Y.; Zhao, Y.; Dong, H.; Deas, T.S.; Zhou, Y.; Li, H.; Shi, P.-Y. West Nile Virus 5'-Cap Structure Is Formed by Sequential Guanine N-7 and Ribose 2'-O Methylations by Nonstructural Protein 5. J. Virol. 2006, 80, 8362-8370. [CrossRef]

38. Krishnan, M.N.; Sukumaran, B.; Pal, U.; Agaisse, H.; Murray, J.L.; Hodge, T.W.; Fikrig, E. Rab 5 Is Required for the Cellular Entry of Dengue and West Nile Viruses. J. Virol. 2007, 81, 4881-4885. [CrossRef]

39. Marianneau, P.; Steffan, A.M.; Royer, C.; Drouet, M.T.; Jaeck, D.; Kirn, A.; Deubel, V. Infection of primary cultures of human Kupffer cells by Dengue virus: No viral progeny synthesis, but cytokine production is evident. J. Virol. 1999, 73, 5201-5206. [CrossRef]

40. Smit, J.M.; Moesker, B.; Rodenhuis-Zybert, I.; Wilschut, J. Flavivirus Cell Entry and Membrane Fusion. Viruses 2011, 3, 160-171. [CrossRef]

41. Perera-Lecoin, M.; Meertens, L.; Carnec, X.; Amara, A. Flavivirus Entry Receptors: An Update. Viruses 2013, 6, 69-88. [CrossRef]

42. Hackett, B.A.; Cherry, S. Flavivirus internalization is regulated by a size-dependent endocytic pathway. Proc. Natl. Acad. Sci. USA 2018, 115, 4246-4251. [CrossRef] [PubMed]

43. Wang, C.; Puerta-Guardo, H.; Biering, S.B.; Glasner, D.R.; Tran, E.B.; Patana, M.; Gomberg, T.A.; Malvar, C.; Lo, N.T.N.; Espinosa, D.A.; et al. Endocytosis of flavivirus NS1 is required for NS1-mediated endothelial hyperpermeability and is abolished by a single N-glycosylation site mutation. PLoS Pathog. 2019, 15, e1007938. [CrossRef]

44. Carro, S.D.; Cherry, S. Beyond the Surface: Endocytosis of Mosquito-Borne Flaviviruses. Viruses 2020, 13, 13. [CrossRef] [PubMed]

45. MacKenzie, J. Wrapping Things up about Virus RNA Replication. Traffic 2005, 6, 967-977. [CrossRef] [PubMed]

46. Mackenzie, J.M.; Westaway, E.G. Assembly and maturation of the flavivirus Kunjin virus appear to occur in the rough endoplasmic reticulum and along the secretory pathway, respectively. J. Virol. 2001, 75, 10787-10799. [CrossRef]

47. Uchil, P.D.; Satchidanandam, V. Architecture of the flaviviral replication complex. Protease, nuclease, and detergents reveal encasement within double-layered membrane compartments. J. Biol. Chem. 2003, 278, 24388-24398. [CrossRef]

48. Heinz, F.X.; Stiasny, K. The Antigenic Structure of Zika Virus and Its Relation to Other Flaviviruses: Implications for Infection and Immunoprophylaxis. Microbiol. Mol. Biol. Rev. 2017, 81, e00055-16. [CrossRef]

49. Wang, P.-G.; Kudelko, M.; Lo, J.; Siu, L.Y.L.; Kwok, K.T.H.; Sachse, M.; Nicholls, J.M.; Bruzzone, R.; Altmeyer, R.M.; Nal, B. Efficient Assembly and Secretion of Recombinant Subviral Particles of the Four Dengue Serotypes Using Native prM and E Proteins. PLoS ONE 2009, 4, e8325. [CrossRef]

50. Gruba, N.; Rodriguez Martinez, J.I.; Grzywa, R.; Wysocka, M.; Skoreński, M.; Burmistrz, M.; Łęcka, M.; Lesner, A.; Sieńczyk, M.; Pyrć, K. Substrate profiling of Zika virus NS2B-NS3 protease. FEBS Lett. 2016, 590, 3459-3468. [CrossRef]

51. Luo, D.; Xu, T.; Hunke, C.; Grüber, G.; Vasudevan, S.; Lescar, J. Crystal Structure of the NS3 Protease-Helicase from Dengue Virus. J. Virol. 2008, 82, 173-183. [CrossRef]

52. Luo, D.; Wei, N.; Doan, D.N.; Paradkar, P.N.; Chong, Y.; Davidson, A.D.; Kotaka, M.; Lescar, J.; Vasudevan, S.G. Flexibility between the Protease and Helicase Domains of the Dengue Virus NS3 Protein Conferred by the Linker Region and Its Functional Implications. J. Biol. Chem. 2010, 285, 18817-18827. [CrossRef]

53. Benzaghou, I.; Bougie, I.; Picard-Jean, F.; Bisaillon, M. Energetics of RNA binding by the West Nile virus RNA triphosphatase. FEBS Lett. 2006, 580, 867-877. [CrossRef] [PubMed]

54. Luo, D.; Xu, T.; Watson, R.P.; Scherer-Becker, D.; Sampath, A.; Jahnke, W.; Yeong, S.S.; Wang, C.H.; Lim, S.P.; Strongin, A.; et al. Insights into RNA unwinding and ATP hydrolysis by the flavivirus NS3 protein. EMBO J. 2008, 27, 3209-3219. [CrossRef]

55. Erbel, P.; Schiering, N.; D’Arcy, A.; Renatus, M.; Kroemer, M.; Lim, S.P.; Yin, Z.; Keller, T.; Vasudevan, S.G.; Hommel, U. Structural basis for the activation of flaviviral NS3 proteases from dengue and West Nile virus. Nat. Struct. Mol. Biol. 2006, 13, $372-373$. [CrossRef] [PubMed]

56. Bazan, J.F.; Fletterick, R.J. Detection of a trypsin-like serine protease domain in flaviviruses and pestiviruses. Virology 1989, 171, 637-639. [CrossRef]

57. Yotmanee, P.; Rungrotmongkol, T.; Wichapong, K.; Choi, S.B.; Wahab, H.A.; Kungwan, N.; Hannongbua, S. Binding specificity of polypeptide substrates in NS2B/NS3pro serine protease of dengue virus type 2: A molecular dynamics Study. J. Mol. Gr. Model. 2015, 60, 24-33. [CrossRef] [PubMed] 
58. Chambers, T.J.; Nestorowicz, A.; Amberg, S.M.; Rice, C.M. Mutagenesis of the yellow fever virus NS2B protein: Effects on proteolytic processing, NS2B-NS3 complex formation, and viral replication. J. Virol. 1993, 67, 6797-6807. [CrossRef] [PubMed]

59. Huang, Q.; Chen, A.S.; Li, Q.; Kang, C. Expression, purification, and initial structural characterization of nonstructural protein 2B, an integral membrane protein of Dengue-2 virus, in detergent micelles. Protein Expr. Purif. 2011, 80, 169-175. [CrossRef] [PubMed]

60. Arias, C.F.; Preugschat, F.; Strauss, J.H. Dengue 2 Virus NS2B and NS3 Form a Stable Complex That Can Cleave NS3 within the Helicase Domain. Virology 1993, 193, 888-899. [CrossRef] [PubMed]

61. Chambers, T.J.; Nestorowicz, A.; Rice, C.M. Mutagenesis of the yellow fever virus NS2B/3 cleavage site: Determinants of cleavage site specificity and effects on polyprotein processing and viral replication. J. Virol. 1995, 69, 1600-1605. [CrossRef] [PubMed]

62. Chambers, T.J.; Droll, D.A.; Tang, Y.; Liang, Y.; Ganesh, V.K.; Murthy, K.H.M.; Nickells, M. Yellow fever virus NS2B-NS3 protease: Characterization of charged-to-alanine mutant and revertant viruses and analysis of polyprotein-cleavage activities. J. Gen. Virol. 2005, 86 Pt 5, 1403-1413. [CrossRef] [PubMed]

63. Clum, S.; Ebner, K.E.; Padmanabhan, R. Cotranslational Membrane Insertion of the Serine Proteinase Precursor NS2B-NS3(Pro) of Dengue Virus Type 2 Is Required for Efficient in Vitro Processing and Is Mediated through the Hydrophobic Regions of NS2B. J. Biol. Chem. 1997, 272, 30715-30723. [CrossRef] [PubMed]

64. Sampath, A.; Padmanabhan, R. Molecular targets for flavivirus drug discovery. Antivir. Res. 2009, 81, 6-15. [CrossRef] [PubMed]

65. Zuo, Z.; Liew, O.W.; Chen, G.; Chong, P.C.J.; Lee, S.H.; Chen, K.; Jiang, H.; Puah, C.M.; Zhu, W. Mechanism of NS2B-Mediated Activation of NS3pro in Dengue Virus: Molecular Dynamics Simulations and Bioassays. J. Virol. 2009, 83, 1060-1070. [CrossRef]

66. Falgout, B.; Miller, R.H.; Lai, C.J. Deletion analysis of dengue virus type 4 nonstructural protein NS2B: Identification of a domain required for NS2B-NS3 protease activity. J. Virol. 1993, 67, 2034-2042. [CrossRef] [PubMed]

67. Bera, A.K.; Kuhn, R.J.; Smith, J.L. Functional Characterization of cis and trans Activity of the Flavivirus NS2B-NS3 Protease. J. Biol. Chem. 2007, 282, 12883-12892. [CrossRef]

68. Aleshin, A.E.; Shiryaev, S.A.; Strongin, A.Y.; Liddington, R.C. Structural evidence for regulation and specificity of flaviviral proteases and evolution of the Flaviviridae fold. Protein Sci. 2007, 16, 795-806. [CrossRef]

69. Chambers, T.J.; Grakoui, A.; Rice, C.M. Processing of the yellow fever virus nonstructural polyprotein: A catalytically active NS3 proteinase domain and NS2B are required for cleavages at dibasic sites. J. Virol. 1991, 65, 6042-6050. [CrossRef]

70. Lin, C.; Amberg, S.M.; Chambers, T.J.; Rice, C.M. Cleavage at a novel site in the NS4A region by the yellow fever virus NS2B-3 proteinase is a prerequisite for processing at the downstream 4A/4B signalase site. J. Virol. 1993, 67, 2327-2335. [CrossRef]

71. Lobigs, M. Flavivirus premembrane protein cleavage and spike heterodimer secretion require the function of the viral proteinase NS3. Proc. Natl. Acad. Sci. USA 1993, 90, 6218-6222. [CrossRef] [PubMed]

72. Li, K.; Phoo, W.W.; Luo, D. Functional interplay among the flavivirus NS3 protease, helicase, and cofactors. Virol. Sin. 2014, 29, 74-85. [CrossRef] [PubMed]

73. Westaway, E.G.; Mackenzie, J.M.; Kenney, M.T.; Jones, M.K.; Khromykh, A.A. Ultrastructure of Kunjin virus-infected cells: Colocalization of NS1 and NS3 with double-stranded RNA, and of NS2B with NS3, in virus-induced membrane structures. J. Virol. 1997, 71, 6650-6661. [CrossRef] [PubMed]

74. Wichapong, K.; Pianwanit, S.; Sippl, W.; Kokpol, S. Homology modeling and molecular dynamics simulations of Dengue virus NS2B/NS3 protease: Insight into molecular interaction. J. Mol. Recognit. 2009, 23, 283-300. [CrossRef]

75. Junaid, M.; Chalayut, C.; Torrejon, A.S.; Angsuthanasombat, C.; Shutava, I.; Lapins, M.; Wikberg, J.E.S.; Katzenmeier, G. Enzymatic Analysis of Recombinant Japanese Encephalitis Virus NS2B(H)-NS3pro Protease with Fluorogenic Model Peptide Substrates. PLoS ONE 2012, 7, e36872. [CrossRef] [PubMed]

76. Leung, D.; Schroder, K.; White, H.; Fang, N.X.; Stoermer, M.J.; Abbenante, G.; Martin, J.L.; Young, P.R.; Fairlie, D.P. Activity of recombinant dengue 2 virus NS3 protease in the presence of a truncated NS2B co-factor, small peptide substrates, and inhibitors. J. Biol. Chem. 2001, 276, 45762-45771. [CrossRef]

77. Yusof, R.; Clum, S.; Wetzel, M.; Murthy, H.M.K.; Padmanabhan, R. Purified NS2B/NS3 Serine Protease of Dengue Virus Type 2 Exhibits Cofactor NS2B Dependence for Cleavage of Substrates with Dibasic Amino Acids in Vitro. J. Biol. Chem. 2000, 275, 9963-9969. [CrossRef] [PubMed]

78. Noble, C.G.; Seh, C.C.; Chao, A.T.; Shi, P.Y. Ligand-bound structures of the dengue virus protease reveal the active conformation. J. Virol. 2012, 86, 438-446. [CrossRef]

79. Falgout, B.; Pethel, M.; Zhang, Y.M.; Lai, C.J. Both nonstructural proteins NS2B and NS3 are required for the proteolytic processing of dengue virus nonstructural proteins. J. Virol. 1991, 65, 2467-2475. [CrossRef]

80. Li, Y.; Li, Q.; Wong, Y.L.; Liew, L.S.Y.; Kang, C. Membrane topology of NS2B of dengue virus revealed by NMR spectroscopy. Biochim. Biophys. Acta Biomembr. 2015, 1848 Pt A, 2244-2252. [CrossRef]

81. Choksupmanee, O.; Hodge, K.; Katzenmeier, G.; Chimnaronk, S. Structural Platform for the Autolytic Activity of an Intact NS2B-NS3 Protease Complex from Dengue Virus. Biochemistry 2012, 51, 2840-2851. [CrossRef] [PubMed]

82. Nitsche, C.; Holloway, S.; Schirmeister, T.; Klein, C. Biochemistry and Medicinal Chemistry of the Dengue Virus Protease. Chem. Rev. 2014, 114, 11348-11381. [CrossRef] [PubMed]

83. Cordero, J.G.; Juárez, M.L.; González-Y-Merchand, J.A.; Barrón, L.C.; Castañeda, B.G. Caveolin-1 in Lipid Rafts Interacts with Dengue Virus NS3 during Polyprotein Processing and Replication in HMEC-1 Cells. PLoS ONE 2014, 9, e90704. 
84. Wu, R.-H.; Tsai, M.-H.; Tsai, K.-N.; Ni Tian, J.; Wu, J.-S.; Wu, S.-Y.; Chern, J.-H.; Chen, C.-H.; Yueh, A. Mutagenesis of Dengue Virus Protein NS2A Revealed a Novel Domain Responsible for Virus-Induced Cytopathic Effect and Interactions between NS2A and NS2B Transmembrane Segments. J. Virol. 2017, 91, e01836-16. [CrossRef]

85. León-Juárez, M.; Martínez-Castillo, M.; Shrivastava, G.; García-Cordero, J.; Villegas-Sepulveda, N.; Mondragón-Castelán, M.; Mondragón-Flores, R.; Cedillo-Barrón, L. Recombinant Dengue virus protein NS2B alters membrane permeability in different membrane models. Virol. J. 2016, 13, 1. [CrossRef]

86. Niyomrattanakit, P.; Winoyanuwattikun, P.; Chanprapaph, S.; Angsuthanasombat, C.; Panyim, S.; Katzenmeier, G. Identification of residues in the dengue virus type 2 NS2B cofactor that are critical for NS3 protease activation. J. Virol. 2004, 78, 13708-13716. [CrossRef]

87. Aguirre, S.; Luthra, P.; Sanchez-Aparicio, M.T.; Maestre, A.M.; Patel, J.; Lamothe, F.; Fredericks, A.C.; Tripathi, S.; Zhu, T.; Pintado-Silva, J.; et al. Dengue virus NS2B protein targets cGAS for degradation and prevents mitochondrial DNA sensing during infection. Nat. Microbiol. 2017, 2, 17037. [CrossRef] [PubMed]

88. Falgout, B.; Markoff, L. Evidence that flavivirus NS1-NS2A cleavage is mediated by a membrane-bound host protease in the endoplasmic reticulum. J. Virol. 1995, 69, 7232-7243. [CrossRef]

89. Amberg, S.M.; Nestorowicz, A.; McCourt, D.W.; Rice, C.M. NS2B-3 proteinase-mediated processing in the yellow fever virus structural region: In vitro and in vivo studies. J. Virol. 1994, 68, 3794-3802. [CrossRef]

90. Cahour, A.; Falgout, B.; Lai, C.J. Cleavage of the dengue virus polyprotein at the NS3/NS4A and NS4B/NS5 junctions is mediated by viral protease NS2B-NS3, whereas NS4A/NS4B may be processed by a cellular protease. J. Virol. 1992, 66, 1535-1542. [CrossRef] [PubMed]

91. Yamshchikov, V.F.; Compans, R.W. Formation of the flavivirus envelope: Role of the viral NS2B-NS3 protease. J. Virol. 1995, 69, 1995-2003. [CrossRef] [PubMed]

92. Nestorowicz, A.; Chambers, T.J.; Rice, C.M. Mutagenesis of the yellow fever virus NS2A/2B cleavage site: Effects on proteolytic processing, viral replication, and evidence for alternative processing of the NS2A protein. Virology 1994, 199, 114-123. [CrossRef]

93. Droll, D.A.; Murthy, H.K.; Chambers, T.J. Yellow Fever Virus NS2B-NS3 Protease: Charged-to-Alanine Mutagenesis and Deletion Analysis Define Regions Important for Protease Complex Formation and Function. Virology 2000, 275, 335-347. [CrossRef] [PubMed]

94. Chen, X.; Yang, K.; Wu, C.; Chen, C.; Hu, C.; Buzovetsky, O.; Wang, Z.; Ji, X.; Xiong, Y.; Yang, H. Mechanisms of activation and inhibition of Zika virus NS2B-NS3 protease. Cell Res. 2016, 26, 1260-1263. [CrossRef] [PubMed]

95. Lei, J.; Hansen, G.; Nitsche, C.; Klein, C.D.; Zhang, L.; Hilgenfeld, R. Crystal structure of Zika virus NS2B-NS3 protease in complex with a boronate inhibitor. Science 2016, 353, 503-505. [CrossRef]

96. Lee, H.; Ren, J.; Nocadello, S.; Rice, A.J.; Ojeda, I.; Light, S.; Minasov, G.; Vargas, J.; Nagarathnam, D.; Anderson, W.F.; et al Identification of novel small molecule inhibitors against NS2B/NS3 serine protease from Zika virus. Antivir. Res. 2017, 139, 49-58. [CrossRef] [PubMed]

97. Giri, R.; Kumar, D.; Sharma, N.; Uversky, V.N. Intrinsically Disordered Side of the Zika Virus Proteome. Front. Cell. Infect. Microbiol. 2016, 6, 144. [CrossRef]

98. Goh, G.K.-M.; Dunker, A.K.; Uversky, V.N. Correlating Flavivirus virulence and levels of intrinsic disorder in shell proteins: Protective roles vs. immune evasion. Mol. BioSyst. 2016, 12, 1881-1891. [CrossRef]

99. Hameed, M.; Wahaab, A.; Nawaz, M.; Khan, S.; Nazir, J.; Liu, K.; Wei, J.; Ma, Z. Potential Role of Birds in Japanese Encephalitis Virus Zoonotic Transmission and Genotype Shift. Viruses 2021, 13, 357. [CrossRef]

100. Gao, X.; Liu, H.; Li, X.; Fu, S.; Cao, L.; Shao, N.; Zhang, W.; Wang, Q.; Lu, Z.; Lei, W.; et al. Changing Geographic Distribution of Japanese Encephalitis Virus Genotypes, 1935-2017. Vector Borne Zoonotic Dis. 2019, 19, 35-44. [CrossRef]

101. Anwar, N.; Wang, X.; Hameed, M.; Wahaab, A.; Li, C.; Sharma, M.; Pang, L.; Malik, M.I.; Liu, K.; Li, B.; et al. Phenotypic and Genotypic Comparison of a Live-Attenuated Genotype I Japanese Encephalitis Virus SD12-F120 Strain with Its Virulent Parental SD12 Strain. Viruses 2020, 12, 552. [CrossRef] [PubMed]

102. Anwar, M.N.; Jiang, C.; Di, D.; Zhang, J.; Guo, S.; Wang, X.; Hameed, M.; Wahaab, A.; Shao, D.; Li, Z.; et al. A Novel Recombinant Virus-Like Particles Displaying B and T Cell Epitopes of Japanese Encephalitis Virus Offers Protective Immunity in Mice and Guinea Pigs. Vaccines 2021, 9, 980. [CrossRef] [PubMed]

103. Ryan, M.D.; Monaghan, S.; Flint, M. Virus-encoded proteinases of the Flaviviridae. J. Gen. Virol. 1998, 79, 947-959. [CrossRef] [PubMed]

104. Li, X.-D.; Deng, C.-L.; Ye, H.-Q.; Zhang, H.-L.; Zhang, Q.-Y.; Chen, D.-D.; Zhang, P.-T.; Shi, P.-Y.; Yuan, Z.-M.; Zhang, B. Transmembrane Domains of NS2B Contribute to both Viral RNA Replication and Particle Formation in Japanese Encephalitis Virus. J. Virol. 2016, 90, 5735-5749. [CrossRef]

105. Luo, D.; Vasudevan, S.G.; Lescar, J. The flavivirus NS2B-NS3 protease-helicase as a target for antiviral drug development. Antivir. Res. 2015, 118, 148-158. [CrossRef]

106. Liang, J.-J.; Liao, C.-L.; Liao, J.-T.; Lee, Y.-L.; Lin, Y.-L. A Japanese encephalitis virus vaccine candidate strain is attenuated by decreasing its interferon antagonistic ability. Vaccine 2009, 27, 2746-2754. [CrossRef]

107. Fan, Y.-C.; Liang, J.-J.; Chen, J.-M.; Lin, J.-W.; Chen, Y.-Y.; Su, K.-H.; Lin, C.-C.; Tu, W.-C.; Chiou, M.-T.; Ou, S.-C.; et al. NS2B/NS3 mutations enhance the infectivity of genotype I Japanese encephalitis virus in amplifying hosts. PLoS Pathog. 2019, 15, e1007992. [CrossRef] 
108. Lin, C.-W.; Huang, H.-D.; Shiu, S.-Y.; Chen, W.-J.; Tsai, M.-H.; Huang, S.-H.; Wan, L.; Lin, Y.-J. Functional determinants of NS2B for activation of Japanese encephalitis virus NS3 protease. Virus Res. 2007, 127, 88-94. [CrossRef]

109. Chappell, K.J.; Stoermer, M.; Fairlie, D.; Young, P.R. Mutagenesis of the West Nile virus NS2B cofactor domain reveals two regions essential for protease activity. J. Gen. Virol. 2008, 89 Pt 4, 1010-1014. [CrossRef]

110. Zhou, H.; Singh, N.J.; Kim, K.S. Homology modeling and molecular dynamics study of West Nile virus NS3 protease: A molecular basis for the catalytic activity increased by the NS2B cofactor. Proteins 2006, 65, 692-701. [CrossRef] [PubMed]

111. Chappell, K.J.; Stoermer, M.; Fairlie, D.; Young, P. West Nile Virus NS2B/NS3 Protease As An Antiviral Target. Curr. Med. Chem. 2008, 15, 2771-2784. [CrossRef]

112. Jia, F.; Fan, J.; Zhang, B.; Yuan, Z. Mutagenesis of D80-82 and G83 residues in West Nile Virus NS2B: Effects on NS2B-NS3 activity and viral replication. Virol. Sin. 2013, 28, 16-23. [CrossRef] [PubMed]

113. Chernov, A.V.; Shiryaev, S.A.; Aleshin, A.E.; Ratnikov, B.I.; Smith, J.W.; Liddington, R.C.; Strongin, A.Y. The Two-component NS2B-NS3 Proteinase Represses DNA Unwinding Activity of the West Nile Virus NS3 Helicase. J. Biol. Chem. 2008, 283, 17270-17278. [CrossRef]

114. Klema, V.J.; Padmanabhan, R.; Choi, K.H. Flaviviral Replication Complex: Coordination between RNA Synthesis and 5'-RNA Capping. Viruses 2015, 7, 4640-4656. [CrossRef] [PubMed]

115. Wang, C.-C.; Huang, Z.-S.; Chiang, P.-L.; Chen, C.-T.; Wu, H.-N. Analysis of the nucleoside triphosphatase, RNA triphosphatase, and unwinding activities of the helicase domain of dengue virus NS3 protein. FEBS Lett. 2009, 583, 691-696. [CrossRef] [PubMed]

116. Su, X.-C.; Ozawa, K.; Qi, R.; Vasudevan, S.; Lim, S.P.; Otting, G. NMR Analysis of the Dynamic Exchange of the NS2B Cofactor between Open and Closed Conformations of the West Nile Virus NS2B-NS3 Protease. PLoS Negl. Trop. Dis. 2009,3, e561. [CrossRef] [PubMed]

117. Robin, G.; Chappell, K.; Stoermer, M.J.; Hu, S.-H.; Young, P.R.; Fairlie, D.P.; Martin, J.L. Structure of West Nile Virus NS3 Protease: Ligand Stabilization of the Catalytic Conformation. J. Mol. Biol. 2009, 385, 1568-1577. [CrossRef]

118. Nall, T.A.; Chappell, K.J.; Stoermer, M.; Fang, N.-X.; Tyndall, J.; Young, P.; Fairlie, D. Enzymatic Characterization and Homology Model of a Catalytically Active Recombinant West Nile Virus NS3 Protease. J. Biol. Chem. 2004, 279, 48535-48542. [CrossRef]

119. Wu, C.-F.; Wang, S.-H.; Sun, C.-M.; Hu, S.-T.; Syu, W.-J. Activation of dengue protease autocleavage at the NS2B-NS3 junction by recombinant NS3 and GST-NS2B fusion proteins. J. Virol. Methods 2003, 114, 45-54. [CrossRef]

120. Pastorino, B.; Peyrefitte, C.N.; Grandadam, M.; Thill, M.C.E.; Tolou, H.J.; Bessaud, M. Mutagenesis analysis of the NS2B determinants of the Alkhurma virus NS2B-NS3 protease activation. J. Gen. Virol. 2006, 87 Pt 11, 3279-3283. [CrossRef]

121. Yang, T.-C.; Shiu, S.-L.; Chuang, P.-H.; Lin, Y.-J.; Wan, L.; Lan, Y.-C.; Lin, C.-W. Japanese encephalitis virus NS2B-NS3 protease induces caspase 3 activation and mitochondria-mediated apoptosis in human medulloblastoma cells. Virus Res. 2009, 143, 77-85. [CrossRef]

122. Chappell, K.J.; Stoermer, M.J.; Fairlie, D.P.; Young, P.R. Insights to substrate binding and processing by West Nile Virus NS3 protease through combined modeling, protease mutagenesis, and kinetic studies. J. Biol. Chem. 2006, 281, 38448-38458. [CrossRef]

123. VanBlargan, L.A.; Davis, K.A.; Dowd, K.A.; Akey, D.L.; Smith, J.L.; Pierson, T.C. Context-Dependent Cleavage of the Capsid Protein by the West Nile Virus Protease Modulates the Efficiency of Virus Assembly. J. Virol. 2015, 89, 8632-8642. [CrossRef] [PubMed]

124. Preugschat, F.; Lenches, E.M.; Strauss, J.H. Flavivirus enzyme-substrate interactions studied with chimeric proteinases: Identification of an intragenic locus important for substrate recognition. J. Virol. 1991, 65, 4749-4758. [CrossRef] [PubMed]

125. Constant, D.A.; Mateo, R.; Nagamine, C.M.; Kirkegaard, K. Targeting intramolecular proteinase NS2B/3 cleavages for transdominant inhibition of dengue virus. Proc. Natl. Acad. Sci. USA 2018, 115, 10136-10141. [CrossRef] [PubMed]

126. Teo, K.F.; Wright, P.J. Internal proteolysis of the NS3 protein specified by dengue virus 2. J. Gen. Virol. 1997, 78 Pt 2, $337-341$. [CrossRef] [PubMed]

127. Shiryaev, S.A.; Farhy, C.; Pinto, A.; Huang, C.-T.; Simonetti, N.; Ngono, A.E.; Dewing, A.; Shresta, S.; Pinkerton, A.B.; Cieplak, P.; et al. Characterization of the Zika virus two-component NS2B-NS3 protease and structure-assisted identification of allosteric small-molecule antagonists. Antivir. Res. 2017, 143, 218-229. [CrossRef]

128. Heaton, N.S.; Perera, R.; Berger, K.L.; Khadka, S.; Lacount, D.J.; Kuhn, R.J.; Randall, G. Dengue virus nonstructural protein 3 redistributes fatty acid synthase to sites of viral replication and increases cellular fatty acid synthesis. Proc. Natl. Acad. Sci. USA 2010, 107, 17345-17350. [CrossRef]

129. Tang, W.-C.; Lin, R.-J.; Liao, C.-L.; Lin, Y.-L. Rab18 Facilitates Dengue Virus Infection by Targeting Fatty Acid Synthase to Sites of Viral Replication. J. Virol. 2014, 88, 6793-6804. [CrossRef] [PubMed]

130. Silva, E.M.; Conde, J.N.; Allonso, D.; Ventura, G.T.; Coelho, D.R.; Carneiro, P.H.; Silva, M.L.; Paes, M.V.; Rabelo, K.; Weissmuller G.; et al. Dengue virus nonstructural 3 protein interacts directly with human glyceraldehyde-3-phosphate dehydrogenase (GAPDH) and reduces its glycolytic activity. Sci. Rep. 2019, 9, 2651. [CrossRef]

131. Bonafé, N.; Gilmore-Hebert, M.; Folk, N.L.; Azodi, M.; Zhou, Y.; Chambers, S.K. Glyceraldehyde-3-Phosphate Dehydrogenase Binds to the AU-Rich 3' Untranslated Region of Colony-Stimulating Factor-1 (CSF-1) Messenger RNA in Human Ovarian Cancer Cells: Possible Role in CSF-1 Posttranscriptional Regulation and Tumor Phenotype. Cancer Res. 2005, 65, 3762-3771. [CrossRef] [PubMed]

132. Ikeda, Y.; Yamaji, R.; Irie, K.; Kioka, N.; Murakami, A. Glyceraldehyde-3-phosphate dehydrogenase regulates cyclooxygenase-2 expression by targeting mRNA stability. Arch. Biochem. Biophys. 2012, 528, 141-147. [CrossRef] [PubMed] 
133. Riedl, W.; Acharya, D.; Lee, J.-H.; Liu, G.; Serman, T.; Chiang, C.; Chan, Y.K.; Diamond, M.S.; Gack, M.U. Zika Virus NS3 Mimics a Cellular 14-3-3-Binding Motif to Antagonize RIG-I- and MDA5-Mediated Innate Immunity. Cell Host Microbe 2019, 26, 493-503.e6. [CrossRef] [PubMed]

134. Tzivion, G.; Shen, Y.H.; Zhu, J. 14-3-3 proteins; bringing new definitions to scaffolding. Oncogene 2001, 20, 6331-6338. [CrossRef]

135. Lennemann, N.J.; Coyne, C.B. Dengue and Zika viruses subvert reticulophagy by NS2B3-mediated cleavage of FAM134B. Autophagy 2017, 13, 322-332. [CrossRef]

136. Li, H.; Saucedo-Cuevas, L.; Yuan, L.; Ross, D.; Johansen, A.; Sands, D.; Stanley, V.; Guemez-Gamboa, A.; Gregor, A.; Evans, T.; et al. Zika Virus Protease Cleavage of Host Protein Septin-2 Mediates Mitotic Defects in Neural Progenitors. Neuron 2019, 101, 1089-1098.e4. [CrossRef] [PubMed]

137. Dong, Y.; Ye, W.; Yang, J.; Han, P.; Wang, Y.; Ye, C.; Weng, D.; Zhang, F.; Xu, Z.; Lei, Y. DDX21 translocates from nucleus to cytoplasm and stimulates the innate immune response due to dengue virus infection. Biochem. Biophys. Res. Commun. 2016, 473, 648-653. [CrossRef] [PubMed]

138. Cao, Y.-Q.; Yuan, L.; Zhao, Q.; Yuan, J.-L.; Miao, C.; Chang, Y.-F.; Wen, X.-T.; Wu, R.; Huang, X.-B.; Wen, Y.-P.; et al. Hsp40 Protein DNAJB6 Interacts with Viral NS3 and Inhibits the Replication of the Japanese Encephalitis Virus. Int. J. Mol. Sci. 2019, $20,5719$. [CrossRef] [PubMed]

139. Neufeldt, C.; Cortese, M.; Acosta, E.G.; Bartenschlager, R. Rewiring cellular networks by members of the Flaviviridae family. Nat. Rev. Genet. 2018, 16, 125-142. [CrossRef] [PubMed]

140. Yu, C.Y.; Liang, J.J.; Li, J.K.; Lee, Y.L.; Chang, B.L.; Su, C.I.; Huang, W.J.; Lai, M.M.; Lin, Y.L. Dengue Virus Impairs Mitochondrial Fusion by Cleaving Mitofusins. PLoS Pathog. 2015, 11, e1005350. [CrossRef] [PubMed]

141. Gandikota, C.; Mohammed, F.; Gandhi, L.; Maisnam, D.; Mattam, U.; Rathore, D.; Chatterjee, A.; Mallick, K.; Billoria, A.; Prasad, V.S.V.; et al. Mitochondrial Import of Dengue Virus NS3 Protease and Cleavage of GrpEL1, a Cochaperone of Mitochondrial Hsp70. J. Virol. 2020, 94, e01178-20. [CrossRef] [PubMed]

142. Mettenleiter, T.C. Breaching the Barrier-The Nuclear Envelope in Virus Infection. J. Mol. Biol. 2016, 428, 1949-1961. [CrossRef]

143. De Jesús-González, L.A.; Palacios-Rápalo, S.; Reyes-Ruiz, J.M.; Osuna-Ramos, J.F.; Cordero-Rivera, C.D.; Farfan-Morales, C.N.; Gutiérrez-Escolano, A.L.; Del Ángel, R.M. The Nuclear Pore Complex Is a Key Target of Viral Proteases to Promote Viral Replication. Viruses 2021, 13, 706. [CrossRef] [PubMed]

144. De Jesús-González, L.A.; Cervantes-Salazar, M.; Reyes-Ruiz, J.M.; Osuna-Ramos, J.F.; Farfán-Morales, C.N.; Palacios-Rápalo, S.N.; Pérez-Olais, J.H.; Cordero-Rivera, C.D.; Hurtado-Monzón, A.M.; Ruíz-Jiménez, F.; et al. The Nuclear Pore Complex: A Target for NS3 Protease of Dengue and Zika Viruses. Viruses 2020, 12, 583. [CrossRef] [PubMed]

145. Hou, W.; Cruz-Cosme, R.; Armstrong, N.; Obwolo, L.A.; Wen, F.; Hu, W.; Luo, M.H.; Tang, Q. Molecular cloning and characterization of the genes encoding the proteins of Zika virus. Gene 2017, 628, 117-128. [CrossRef] [PubMed]

146. Cortese, M.; Goellner, S.; Acosta, E.G.; Neufeldt, C.; Oleksiuk, O.; Lampe, M.; Haselmann, U.; Funaya, C.; Schieber, N.; Ronchi, P.; et al. Ultrastructural Characterization of Zika Virus Replication Factories. Cell Rep. 2017, 18, 2113-2123. [CrossRef] [PubMed]

147. Reyes-Ruiz, J.M.; Osuna-Ramos, J.F.; Cervantes-Salazar, M.; Guillen, A.E.L.; Chávez-Munguía, B.; Salas-Benito, J.S.; Del Ángel, R.M. Strand-like structures and the nonstructural proteins 5, 3 and 1 are present in the nucleus of mosquito cells infected with dengue virus. Virology 2018, 515, 74-80. [CrossRef] [PubMed]

148. Palacios-Rápalo, S.N.; De Jesús-González, L.A.; Reyes-Ruiz, J.M.; Osuna-Ramos, J.F.; Farfan-Morales, C.N.; Gutiérrez-Escolano, A.L.; del Ángel, R.M. Nuclear localization of non-structural protein 3 (NS3) during dengue virus infection. Arch. Virol. 2021, 166, 1439-1446. [CrossRef] [PubMed]

149. Shiryaev, S.A.; Ratnikov, B.I.; Aleshin, A.E.; Kozlov, I.A.; Nelson, N.A.; Lebl, M.; Smith, J.W.; Liddington, R.C.; Strongin, A.Y. Switching the Substrate Specificity of the Two-Component NS2B-NS3 Flavivirus Proteinase by Structure-Based Mutagenesis. J. Virol. 2007, 81, 4501-4509. [CrossRef]

150. Jan, L.-R.; Yang, C.-S.; Trent, D.W.; Falgout, B.; Lai, C.-J. Processing of Japanese encephalitis virus non-structural proteins: NS2B-NS3 complex and heterologous proteases. J. Gen. Virol. 1995, 76 Pt 3, 573-580. [CrossRef] [PubMed]

151. Sumiyoshi, H.; Mori, C.; Fuke, I.; Morita, K.; Kuhara, S.; Kondou, J.; Kikuchi, Y.; Nagamatu, H.; Igarashi, A. Complete nucleotide sequence of the Japanese encephalitis virus genome RNA. Virology 1987, 161, 497-510. [CrossRef]

152. Rice, C.M.; Lenches, E.M.; Eddy, S.R.; Shin, S.J.; Sheets, R.L.; Strauss, J.H. Nucleotide sequence of yellow fever virus: Implications for flavivirus gene expression and evolution. Science 1985, 229, 726-733. [CrossRef] [PubMed]

153. Wengler, G.; Castle, E.; Leidner, U.; Nowak, T.; Wengler, G. Sequence analysis of the membrane protein V3 of the flavivirus west nile virus and of its gene. Virology 1985, 147, 264-274. [CrossRef]

154. Castle, E.; Leidner, U.; Nowak, T.; Wengler, G.; Wengler, G. Primary structure of the West Nile flavivirus genome region coding for all nonstructural proteins. Virology 1986, 149, 10-26. [CrossRef]

155. Wengler, G.; Wengler, G. Cell-associated West Nile flavivirus is covered with E+pre-M protein heterodimers which are destroyed and reorganized by proteolytic cleavage during virus release. J. Virol. 1989, 63, 2521-2526. [CrossRef] [PubMed]

156. Mundt, E.; Muller, H. Complete Nucleotide Sequences of 5'- and 3'-Noncoding Regions of Both Genome Segments of Different Strains of Infectious Bursal Disease Virus. Virology 1995, 209, 10-18. [CrossRef]

157. Morazzani, E.M.; Compton, J.R.; Leary, D.H.; Berry, A.V.; Hu, X.; Marugan, J.J.; Glass, P.J.; Legler, P.M. Proteolytic cleavage of host proteins by the Group IV viral proteases of Venezuelan equine encephalitis virus and Zika virus. Antivir. Res. 2019, 164, 106-122. [CrossRef] [PubMed] 
158. Mason, P.W.; McAda, P.C.; Mason, T.L.; Fournier, M.J. Sequence of the dengue-1 virus genome in the region encoding the three structural proteins and the major nonstructural protein NS1. Virology 1987, 161, 262-267. [CrossRef]

159. Hahn, Y.S.; Caller, R.; Hunkapiller, T.; Dalrymple, J.M.; Strauss, J.H.; Strauss, E.G. Nucleotide sequence of dengue 2 RNA and comparison of the encoded proteins with those of other flaviviruses. Virology 1988, 162, 167-180. [CrossRef]

160. Osatomi, K.; Fuke, I.; Tsuru, D.; Shiba, T.; Sakaki, Y.; Sumiyoshi, H. Nucleotide sequence of dengue type 3 virus genomic RNA encoding viral structural proteins. Virus Genes 1988, 2, 99-108. [CrossRef] [PubMed]

161. Mackow, E.; Makino, Y.; Zhao, B.T.; Zhang, Y.M.; Markoff, L.; Buckler-White, A.; Guiler, M.; Chanock, R.; Lai, C.J. The nucleotide sequence of dengue type 4 virus: Analysis of genes coding for nonstructural proteins. Virology 1987, 159, 217-228. [CrossRef]

162. Zhao, B.; Mackow, E.; Buckler-White, A.; Markoff, L.; Chanock, R.M.; Lai, C.-J.; Making, Y. Cloning full-length dengue type 4 viral DNA sequences: Analysis of genes coding for structural proteins. Virology 1986, 155, 77-88. [CrossRef]

163. Mueller, N.H.; Yon, C.; Ganesh, V.K.; Padmanabhan, R. Characterization of the West Nile virus protease substrate specificity and inhibitors. Int. J. Biochem. Cell Biol. 2007, 39, 606-614. [CrossRef] [PubMed]

164. Li, Y.; Zhang, Z.; Phoo, W.W.; Loh, Y.R.; Wang, W.; Liu, S.; Chen, M.W.; Hung, A.W.; Keller, T.H.; Luo, D.; et al. Structural Dynamics of Zika Virus NS2B-NS3 Protease Binding to Dipeptide Inhibitors. Structure 2017, 25, 1242-1250.e3. [CrossRef] [PubMed]

165. Phoo, W.W.; Li, Y.; Zhang, Z.; Lee, M.Y.; Loh, Y.R.; Tan, Y.B.; Ng, E.Y.; Lescar, J.; Kang, C.; Luo, D. Structure of the NS2B-NS3 protease from Zika virus after self-cleavage. Nat. Commun. 2016, 7, 13410. [CrossRef]

166. Kondo, M.Y.; Oliveira, L.C.; Okamoto, D.N.; De Araujo, M.R.; Dos Santos, C.N.D.; Juliano, M.A.; Juliano, L.; Gouvea, I.E. Yellow fever virus NS2B/NS3 protease: Hydrolytic Properties and Substrate Specificity. Biochem. Biophys. Res. Commun. 2011, 407, 640-644. [CrossRef] [PubMed]

167. De Clercq, E.; Li, G. Approved Antiviral Drugs over the Past 50 Years. Clin. Microbiol. Rev. 2016, 29, 695-747. [CrossRef] [PubMed]

168. Lim, S.P.; Wang, Q.-Y.; Noble, C.G.; Chen, Y.-L.; Dong, H.; Zou, B.; Yokokawa, F.; Nilar, S.; Smith, P.; Beer, D.; et al. Ten years of dengue drug discovery: Progress and prospects. Antivir. Res. 2013, 100, 500-519. [CrossRef] [PubMed]

169. Niyomrattanakit, P.; Yahorava, S.; Mutule, I.; Mutulis, F.; Petrovska, R.; Prusis, P.; Katzenmeier, G.; Wikberg, J.E.S. Probing the substrate specificity of the dengue virus type 2 NS3 serine protease by using internally quenched fluorescent peptides. Biochem. J. 2006, 397, 203-211. [CrossRef]

170. Yin, Z.; Patel, S.J.; Wang, W.-L.; Chan, W.-L.; Rao, K.R.; Wang, G.; Ngew, X.; Patel, V.; Beer, D.; Knox, J.E.; et al. Peptide inhibitors of dengue virus NS3 protease. Part 2: SAR study of tetrapeptide aldehyde inhibitors. Bioorganic Med. Chem. Lett. 2006, 16, 40-43. [CrossRef]

171. Adamek, R.N.; Maniquis, R.V.; Khakoo, S.; Bridges, M.D.; Salzameda, N.T. A FRET-based assay for the discovery of West Nile Virus NS2B-NS3 protease inhibitors. Bioorg. Med. Chem. Lett. 2013, 23, 4848-4850. [CrossRef] [PubMed]

172. Behnam, M.A.M.; Graf, D.; Bartenschlager, R.; Zlotos, D.P.; Klein, C.D. Discovery of Nanomolar Dengue and West Nile Virus Protease Inhibitors Containing a 4-Benzyloxyphenylglycine Residue. J. Med. Chem. 2015, 58, 9354-9370. [CrossRef]

173. Nitsche, C.; Zhang, L.; Weigel, L.F.; Schilz, J.; Graf, D.; Bartenschlager, R.; Hilgenfeld, R.; Klein, C.D. Peptide-Boronic Acid Inhibitors of Flaviviral Proteases: Medicinal Chemistry and Structural Biology. J. Med. Chem. 2017, 60, 511-516. [CrossRef] [PubMed]

174. Schüller, A.; Yin, Z.; Brian Chia, C.S.; Doan, D.N.; Kim, H.K.; Shang, L.; Loh, T.P.; Hill, J.; Vasudevan, S.G. Tripeptide inhibitors of dengue and West Nile virus NS2B-NS3 protease. Antivir. Res. 2011, 92, 96-101. [CrossRef] [PubMed]

175. Shiryaev, S.A.; Ratnikov, B.I.; Chekanov, A.V.; Sikora, S.; Rozanov, D.V.; Godzik, A.; Wang, J.; Smith, J.W.; Huang, Z.; Lindberg, I.; et al. Cleavage targets and the D-arginine-based inhibitors of the West Nile virus NS3 processing proteinase. Biochem. J. 2006, 393 Pt 2, 503-511. [CrossRef]

176. Stoermer, M.J.; Chappell, K.J.; Liebscher, S.; Jensen, C.M.; Gan, C.H.; Gupta, P.K.; Xu, W.J.; Young, P.R.; Fairlie, D.P. Potent cationic inhibitors of West Nile virus NS2B/NS3 protease with serum stability, cell permeability and antiviral activity. J. Med. Chem. 2008, 51, 5714-5721. [CrossRef]

177. Knox, J.E.; Ma, N.L.; Yin, Z.; Patel, S.J.; Wang, W.-L.; Chan, W.-L.; Rao, K.R.R.; Wang, G.; Ngew, X.; Patel, V.; et al. Peptide Inhibitors of West Nile NS3 Protease: SAR Study of Tetrapeptide Aldehyde Inhibitors. J. Med. Chem. 2006, 49, 6585-6590. [CrossRef]

178. Behnam, M.; Nitsche, C.; Vechi, S.M.; Klein, C.D. C-Terminal Residue Optimization and Fragment Merging: Discovery of a Potent Peptide-Hybrid Inhibitor of Dengue Protease. ACS Med. Chem. Lett. 2014, 5, 1037-1042. [CrossRef]

179. Bastos Lima, A.; Behnam, M.A.; El Sherif, Y.; Nitsche, C.; Vechi, S.M.; Klein, C.D. Dual inhibitors of the dengue and West Nile virus NS2B-NS3 proteases: Synthesis, biological evaluation and docking studies of novel peptide-hybrids. Bioorg. Med. Chem. 2015, 23, 5748-5755. [CrossRef]

180. Jia, F.; Zou, G.; Fan, J.; Yuan, Z. Identification of palmatine as an inhibitor of West Nile virus. Arch. Virol. 2010, 155, 1325-1329. [CrossRef]

181. Cregar-Hernandez, L.; Jiao, G.-S.; Johnson, A.T.; Lehrer, A.T.; Wong, T.A.S.; Margosiak, S.A. Small Molecule Pan-Dengue and West Nile Virus NS3 Protease Inhibitors. Antivir. Chem. Chemother. 2011, 21, 209-217. [CrossRef]

182. Kouretova, J.; Hammamy, M.Z.; Epp, A.; Hardes, K.; Kallis, S.; Zhang, L.; Hilgenfeld, R.; Bartenschlager, R.; Steinmetzer, T. Effects of NS2B-NS3 protease and furin inhibition on West Nile and Dengue virus replication. J. Enzym. Inhib. Med. Chem. 2017, 32, 712-721. [CrossRef] [PubMed] 
183. Nitsche, C.; Schreier, V.N.; Behnam, M.A.M.; Kumar, A.; Bartenschlager, R.; Klein, C.D. Thiazolidinone-Peptide Hybrids as Dengue Virus Protease Inhibitors with Antiviral Activity in Cell Culture. J. Med. Chem. 2013, 56, 8389-8403. [CrossRef] [PubMed]

184. Rothan, H.A.; Mohamed, Z.; Suhaeb, A.M.; Rahman, N.A.; Yusof, R. Antiviral Cationic Peptides as a Strategy for Innovation in Global Health Therapeutics for Dengue Virus: High Yield Production of the Biologically Active Recombinant Plectasin Peptide. OMICS J. Integr. Biol. 2013, 17, 560-567. [CrossRef] [PubMed]

185. Weigel, L.F.; Nitsche, C.; Graf, D.; Bartenschlager, R.; Klein, C.D. Phenylalanine and Phenylglycine Analogues as Arginine Mimetics in Dengue Protease Inhibitors. J. Med. Chem. 2015, 58, 7719-7733. [CrossRef]

186. Tambunan, U.S.F.; Alamudi, S. Designing cyclic peptide inhibitor of dengue virus NS3-NS2B protease by using molecular docking approach. Bioinformation 2010, 5, 250-254. [CrossRef] [PubMed]

187. Yang, C.C.; Hsieh, Y.C.; Lee, S.J.; Wu, S.H.; Liao, C.L.; Tsao, C.H.; Chao, Y.S.; Chern, J.H.; Wu, C.P.; Yueh, A. Novel dengue virus-specific NS2B/NS3 protease inhibitor, BP2109, discovered by a high-throughput screening assay. Antimicrob. Agents Chemother. 2011, 55, 229-238. [CrossRef]

188. Yang, C.-C.; Hu, H.-S.; Wu, R.-H.; Wu, S.-H.; Lee, S.-J.; Jiaang, W.-T.; Chern, J.-H.; Huang, Z.-S.; Wu, H.-N.; Chang, C.-M.; et al. A Novel Dengue Virus Inhibitor, BP13944, Discovered by High-Throughput Screening with Dengue Virus Replicon Cells Selects for Resistance in the Viral NS2B/NS3 Protease. Antimicrob. Agents Chemother. 2014, 58, 110-119. [CrossRef]

189. Beesetti, H.; Tyagi, P.; Medapi, B.; Krishna, V.S.; Sriram, D.; Khanna, N.; Swaminathan, S. A quinoline compound inhibits the replication of dengue virus serotypes 1-4 in Vero cells. Antivir. Ther. 2018, 23, 385-394. [CrossRef]

190. Aravapalli, S.; Lai, H.; Teramoto, T.; Alliston, K.R.; Lushington, G.H.; Ferguson, E.L.; Padmanabhan, R.; Groutas, W.C. Inhibitors of Dengue virus and West Nile virus proteases based on the aminobenzamide scaffold. Bioorg. Med. Chem. 2012, 20, 4140-4148. [CrossRef]

191. Nie, S.; Yao, Y.; Wu, F.; Wu, X.; Zhao, J.; Hua, Y.; Wu, J.; Huo, T.; Lin, Y.L.; Kneubehl, A.R.; et al. Synthesis, Structure-Activity Relationships, and Antiviral Activity of Allosteric Inhibitors of Flavivirus NS2B-NS3 Protease. J. Med. Chem. 2021, 64, 2777-2800 [CrossRef]

192. Rothan, H.A.; Abdulrahman, A.Y.; Sasikumar, P.G.; Othman, S.; Rahman, N.A.; Yusof, R. Protegrin-1 Inhibits Dengue NS2B-NS3 Serine Protease and Viral Replication in MK2 Cells. J. Biomed. Biotechnol. 2012, 2012, 251482. [CrossRef] [PubMed]

193. Rothan, H.A.; Han, H.C.; Ramasamy, T.S.; Othman, S.; Rahman, N.A.; Yusof, R. Inhibition of dengue NS2B-NS3 protease and viral replication in Vero cells by recombinant retrocyclin-1. BMC Infect. Dis. 2012, 12, 314. [CrossRef]

194. Kiat, T.S.; Pippen, R.; Yusof, R.; Ibrahim, H.; Khalid, N.; Rahman, N.A. Inhibitory activity of cyclohexenyl chalcone derivatives and flavonoids of fingerroot, Boesenbergia rotunda (L.), towards dengue-2 virus NS3 protease. Bioorg. Med. Chem. Lett. 2006, 16, 3337-3340. [CrossRef]

195. Tomlinson, S.M.; Watowich, S.J. Use of parallel validation high-throughput screens to reduce false positives and identify novel dengue NS2B-NS3 protease inhibitors. Antivir. Res. 2012, 93, 245-252. [CrossRef] [PubMed]

196. Nitsche, C.; Behnam, M.; Steuer, C.; Klein, C.D. Retro peptide-hybrids as selective inhibitors of the Dengue virus NS2B-NS3 protease. Antivir. Res. 2012, 94, 72-79. [CrossRef]

197. Chan, J.F.-W.; Chik, K.K.-H.; Yuan, S.; Yip, C.C.-Y.; Zhu, Z.; Tee, K.-M.; Tsang, J.O.-L.; Chan, C.C.-S.; Poon, V.K.-M.; Lu, G.; et al Novel antiviral activity and mechanism of bromocriptine as a Zika virus NS2B-NS3 protease inhibitor. Antivir. Res. 2017, 141, 29-37. [CrossRef] [PubMed]

198. Yuan, S.; Chan, J.F.; den-Haan, H.; Chik, K.K.; Zhang, A.J.; Chan, C.C.; Poon, V.K.; Yip, C.C.; Mak, W.W.; Zhu, Z.; et al. Structurebased discovery of clinically approved drugs as Zika virus NS2B-NS3 protease inhibitors that potently inhibit Zika virus infection in vitro and in vivo. Antivir. Res. 2017, 145, 33-43. [CrossRef] [PubMed]

199. Kumar, A.; Liang, B.; Aarthy, M.; Singh, S.K.; Garg, N.; Mysorekar, I.U.; Giri, R. Hydroxychloroquine Inhibits Zika Virus NS2B-NS3 Protease. ACS Omega 2018, 3, 18132-18141. [CrossRef]

200. Li, Z.; Sakamuru, S.; Huang, R.; Brecher, M.; Koetzner, C.A.; Zhang, J.; Chen, H.; Qin, C.-F.; Zhang, Q.-Y.; Zhou, J.; et al. Erythrosin $\mathrm{B}$ is a potent and broad-spectrum orthosteric inhibitor of the flavivirus NS2B-NS3 protease. Antivir. Res. 2017, 150, 217-225. [CrossRef]

201. Cui, X.; Zhou, R.; Huang, C.; Zhang, R.; Wang, J.; Zhang, Y.; Ding, J.; Li, X.; Zhou, J.; Cen, S. Identification of Theaflavin-3,3'Digallate as a Novel Zika Virus Protease Inhibitor. Front. Pharmacol. 2020, 11, 514313. [CrossRef] [PubMed]

202. Akaberi, D.; Chinthakindi, P.K.; Båhlström, A.; Palanisamy, N.; Sandström, A.; Lundkvist, Å.; Lennerstrand, J. Identification of a C2-symmetric diol based human immunodeficiency virus protease inhibitor targeting Zika virus NS2B-NS3 protease. J. Biomol. Struct. Dyn. 2020, 38, 5526-5536. [CrossRef] [PubMed]

203. Brecher, M.; Li, Z.; Liu, B.; Zhang, J.; Koetzner, C.A.; Alifarag, A.; Jones, S.A.; Lin, Q.; Kramer, L.D.; Li, H. A conformational switch high-throughput screening assay and allosteric inhibition of the flavivirus NS2B-NS3 protease. PLoS Pathog. 2017, 13, e1006411. [CrossRef] [PubMed]

204. An, J.; Kimura-Kuroda, J.; Hirabayashi, Y.; Yasui, K. Development of a novel mouse model for dengue virus infection. Virology 1999, 263, 70-77. [CrossRef] [PubMed]

205. Bente, D.A.; Melkus, M.W.; Garcia, J.V.; Rico-Hesse, R. Dengue Fever in Humanized NOD/SCID Mice. J. Virol. 2005, 79, 13797-13799. [CrossRef]

206. Cox, J.; Mota, J.; Sukupolvi-Petty, S.; Diamond, M.S.; Rico-Hesse, R. Mosquito bite delivery of dengue virus enhances immunogenicity and pathogenesis in humanized mice. J. Virol. 2012, 86, 7637-7649. [CrossRef] [PubMed] 
207. Jaiswal, S.; Pearson, T.; Friberg, H.; Shultz, L.D.; Greiner, D.L.; Rothman, A.L.; Mathew, A. Dengue virus infection and virusspecific HLA-A2 restricted immune responses in humanized NOD-scid IL2rgammanull mice. PLoS ONE 2009, 4, e7251. [CrossRef] [PubMed]

208. Jaiswal, S.; Pazoles, P.; Woda, M.; Shultz, L.D.; Greiner, D.L.; Brehm, M.A.; Mathew, A. Enhanced humoral and HLA-A2-restricted dengue virus-specific T-cell responses in humanized BLT NSG mice. Immunology 2012, 136, 334-343. [CrossRef]

209. Kuruvilla, J.G.; Troyer, R.M.; Devi, S.; Akkina, R. Dengue virus infection and immune response in humanized RAG2(-/)gamma(c)(-/-) (RAG-hu) mice. Virology 2007, 369, 143-152. [CrossRef] [PubMed]

210. Lin, Y.-L.; Liao, C.-L.; Chen, L.-K.; Yeh, C.-T.; Liu, C.-I.; Ma, S.-H.; Huang, Y.-Y.; Huang, Y.-L.; Kao, C.-L.; King, C.-C. Study of Dengue Virus Infection in SCID Mice Engrafted with Human K562 Cells. J. Virol. 1998, 72, 9729-9737. [CrossRef] [PubMed]

211. Mota, J.; Rico-Hesse, R. Humanized Mice Show Clinical Signs of Dengue Fever according to Infecting Virus Genotype. J. Virol. 2009, 83, 8638-8645. [CrossRef] [PubMed]

212. Sridharan, A.; Chen, Q.; Tang, K.F.; Ooi, E.E.; Hibberd, M.L.; Chen, J. Inhibition of Megakaryocyte Development in the Bone Marrow Underlies Dengue Virus-Induced Thrombocytopenia in Humanized Mice. J. Virol. 2013, 87, 11648-11658. [CrossRef] [PubMed]

213. Alves dos Santos, E.; Fink, K. Animal Models for Dengue and Zika Vaccine Development. In Dengue and Zika: Control and Antiviral Treatment Strategies; Hilgenfeld, R., Vasudevan, S.G., Eds.; Springer: Singapore, 2018; pp. 215-239.

214. Coronel-Ruiz, C.; Gutiérrez-Barbosa, H.; Medina-Moreno, S.; Velandia-Romero, M.L.; Chua, J.V.; Castellanos, J.E.; Zapata, J.C. Humanized Mice in Dengue Research: A Comparison with Other Mouse Models. Vaccines 2020, 8, 39. [CrossRef] [PubMed]

215. Ding, Q.; Gaska, J.M.; Douam, F.; Wei, L.; Kim, D.; Balev, M.; Heller, B.; Ploss, A. Species-specific disruption of STING-dependent antiviral cellular defenses by the Zika virus NS2B3 protease. Proc. Natl. Acad. Sci. USA 2018, 115, E6310-E6318. [CrossRef] [PubMed]

216. Burdette, D.L.; Vance, R.E. STING and the innate immune response to nucleic acids in the cytosol. Nat. Immunol. 2013, 14, 19-26. [CrossRef] [PubMed]

217. Ishikawa, H.; Ma, Z.; Barber, G.N. STING regulates intracellular DNA-mediated, type I interferon-dependent innate immunity Nature 2009, 461, 788-792. [CrossRef] [PubMed]

218. Ishikawa, H.; Barber, G.N. STING is an endoplasmic reticulum adaptor that facilitates innate immune signalling. Nature 2008, 455, 674-678. [CrossRef]

219. Zhong, B.; Yang, Y.; Li, S.; Wang, Y.-Y.; Li, Y.; Diao, F.; Lei, C.; He, X.; Zhang, L.; Tien, P.; et al. The Adaptor Protein MITA Links Virus-Sensing Receptors to IRF3 Transcription Factor Activation. Immunity 2008, 29, 538-550. [CrossRef] [PubMed]

220. Zhang, Z.; Yuan, B.; Bao, M.; Lu, N.; Kim, T.; Liu, Y.-J. The helicase DDX41 senses intracellular DNA mediated by the adaptor STING in dendritic cells. Nat. Immunol. 2011, 12, 959-965. [CrossRef]

221. Holm, C.K.; Rahbek, S.H.; Gad, H.H.; Bak, R.O.; Jakobsen, M.R.; Jiang, Z.; Hansen, A.L.; Jensen, S.K.; Sun, C.; Thomsen, M.K.; et al. Influenza A virus targets a cGAS-independent STING pathway that controls enveloped RNA viruses. Nature Commun. 2016, 7, 10680. [CrossRef]

222. Aguirre, S.; Maestre, A.M.; Pagni, S.; Patel, J.R.; Savage, T.; Gutman, D.; Maringer, K.; Bernal-Rubio, D.; Shabman, R.S.; Simon, V.; et al. DENV Inhibits Type I IFN Production in Infected Cells by Cleaving Human STING. PLoS Pathog. 2012, 8, e1002934. [CrossRef] [PubMed]

223. Nitta, S.; Sakamoto, N.; Nakagawa, M.; Kakinuma, S.; Mishima, K.; Kusano-Kitazume, A.; Kiyohashi, K.; Murakawa, M.; Nishimura-Sakurai, Y.; Azuma, S.; et al. Hepatitis C virus NS4B protein targets STING and abrogates RIG-I-mediated type I interferon-dependent innate immunity. Hepatology 2013, 57, 46-58. [CrossRef]

224. Sun, L.; Xing, Y.; Chen, X.; Zheng, Y.; Yang, Y.; Nichols, D.B.; Clementz, M.A.; Banach, B.S.; Li, K.; Baker, S.C.; et al. Coronavirus Papain-like Proteases Negatively Regulate Antiviral Innate Immune Response through Disruption of STING-Mediated Signaling. PLOS ONE 2012, 7, e30802. [CrossRef]

225. Yu, C.-Y.; Chang, T.-H.; Liang, J.-J.; Chiang, R.-L.; Lee, Y.-L.; Liao, C.-L.; Lin, Y.-L. Dengue Virus Targets the Adaptor Protein MITA to Subvert Host Innate Immunity. PLoS Pathog. 2012, 8, e1002780. [CrossRef] [PubMed]

226. Stabell, A.C.; Meyerson, N.R.; Gullberg, R.C.; Gilchrist, A.R.; Webb, K.J.; Old, W.M.; Perera, R.; Sawyer, S.L. Dengue viruses cleave STING in humans but not in nonhuman primates, their presumed natural reservoir. eLife 2018, 7, e31919. [CrossRef]

227. Ashour, J.; Morrison, J.; Laurent-Rolle, M.; Belicha-Villanueva, A.; Plumlee, C.R.; Bernal-Rubio, D.; Williams, K.L.; Harris, E.; Fernandez-Sesma, A.; Schindler, C.; et al. Mouse STAT2 Restricts Early Dengue Virus Replication. Cell Host Microbe 2010, 8 , 410-421. [CrossRef]

228. Jones, M.; Davidson, A.; Hibbert, L.; Gruenwald, P.; Schlaak, J.; Ball, S.; Foster, G.R.; Jacobs, M. Dengue Virus Inhibits Alpha Interferon Signaling by Reducing STAT2 Expression. J. Virol. 2005, 79, 5414-5420. [CrossRef] [PubMed]

229. Mazzon, M.; Jones, M.; Davidson, A.; Chain, B.; Jacobs, M. Dengue Virus NS5 Inhibits Interferon- $\alpha$ Signaling by Blocking Signal Transducer and Activator of Transcription 2 Phosphorylation. J. Infect. Dis. 2009, 200, 1261-1270. [CrossRef] [PubMed]

230. Morrison, J.; Aguirre, S.; Fernandez-Sesma, A. Innate Immunity Evasion by Dengue Virus. Viruses 2012, 4, 397-413. [CrossRef]

231. Zompi, S.; Harris, E. Animal Models of Dengue Virus Infection. Viruses 2012, 4, 62-82. [CrossRef] [PubMed]

232. Putnak, R.; Barvir, D.A.; Burrous, J.M.; Dubois, D.R.; D'Andrea, V.M.; Hoke, C.H.; Sadoff, J.C.; Eckels, K.H. Development of a Purified, Inactivated, Dengue-2 Virus Vaccine Prototype in Vero Cells: Immunogenicity and Protection in Mice and Rhesus Monkeys. J. Infect. Dis. 1996, 174, 1176-1184. [CrossRef] 
233. Men, R.; Wyatt, L.; Tokimatsu, I.; Arakaki, S.; Shameem, G.; Elkins, R.; Chanock, R.; Moss, B.; Lai, C.-J. Immunization of rhesus monkeys with a recombinant of modified vaccinia virus Ankara expressing a truncated envelope glycoprotein of dengue type 2 virus induced resistance to dengue type 2 virus challenge. Vaccine 2000, 18, 3113-3122. [CrossRef]

234. Putnak, R.; Fuller, J.; VanderZanden, L.; Innis, B.L.; Vaughn, D.W. Vaccination of rhesus macaques against dengue-2 virus with a plasmid DNA vaccine encoding the viral pre-membrane and envelope genes. Am. J. Trop. Med. Hyg. 2003, 68, 469-476. [CrossRef] [PubMed]

235. Raviprakash, K.; Porter, K.R.; Kochel, T.J.; Ewing, D.; Simmons, M.; Phillips, I.; Murphy, G.S.; Weiss, W.R.; Hayes, C.G. Dengue virus type 1 DNA vaccine induces protective immune responses in rhesus macaques. Microbiology 2000, 81 Pt 7, $1659-1667$. [CrossRef] [PubMed]

236. Raviprakash, K.; Apt, D.; Brinkman, A.; Skinner, C.; Yang, S.; Dawes, G.; Ewing, D.; Wu, S.-J.; Bass, S.; Punnonen, J.; et al. A chimeric tetravalent dengue DNA vaccine elicits neutralizing antibody to all four virus serotypes in rhesus macaques. Virology 2006, 353, 166-173. [CrossRef] [PubMed]

237. Raviprakash, K.; Wang, D.; Ewing, D.; Holman, D.H.; Block, K.; Woraratanadharm, J.; Chen, L.; Hayes, C.; Dong, J.Y.; Porter, K. A Tetravalent Dengue Vaccine Based on a Complex Adenovirus Vector Provides Significant Protection in Rhesus Monkeys against All Four Serotypes of Dengue Virus. J. Virol. 2008, 82, 6927-6934. [CrossRef]

238. Zhang, Y.; Wei, Y.; Zhang, X.; Cai, H.; Niewiesk, S.; Li, J. Rational Design of Human Metapneumovirus Live Attenuated Vaccine Candidates by Inhibiting Viral mRNA Cap Methyltransferase. J. Virol. 2014, 88, 11411-11429. [CrossRef] [PubMed]

239. Fernandez, S.; Thomas, S.J.; De La Barrera, R.; Im-Erbsin, R.; Jarman, R.G.; Baras, B.; Toussaint, J.-F.; Mossman, S.; Innis, B.; Schmidt, A.; et al. An Adjuvanted, Tetravalent Dengue Virus Purified Inactivated Vaccine Candidate Induces Long-Lasting and Protective Antibody Responses Against Dengue Challenge in Rhesus Macaques. Am. J. Trop. Med. Hyg. 2015, 92, 698-708. [CrossRef]

240. McBurney, S.P.; Sunshine, J.E.; Gabriel, S.; Huynh, J.P.; Sutton, W.F.; Fuller, D.; Haigwood, N.; Messer, W.B. Evaluation of protection induced by a dengue virus serotype 2 envelope domain III protein scaffold/DNA vaccine in non-human primates. Vaccine 2016, 34, 3500-3507. [CrossRef]

241. Velzing, J.; Groen, J.; Drouet, M.T.; van Amerongen, G.; Copra, C.; Osterhaus, A.D.; Deubel, V. Induction of protective immunity against Dengue virus type 2: Comparison of candidate live attenuated and recombinant vaccines. Vaccine 1999, 17, 1312-1320. [CrossRef]

242. Butrapet, S.; Rabablert, J.; Angsubhakorn, S.; Wiriyarat, W.; Huang, C.; Kinney, R.; Punyim, S.; Bhamarapravati, N. Chimeric dengue type 2/type 1 viruses induce immune responses in cynomolgus monkeys. S. Asian J. Trop. Med. Public Health 2002, 33, 589-599.

243. Hermida, L.; Bernardo, L.; Martín, J.; Alvarez, M.; Prado, I.; López, C.; Sierra, B.D.L.C.; Martínez, R.; Rodríguez, R.; Zulueta, A. A recombinant fusion protein containing the domain III of the dengue-2 envelope protein is immunogenic and protective in nonhuman primates. Vaccine 2006, 24, 3165-3171. [CrossRef]

244. Izquierdo, A.; Bernardo, L.; Martin, J.; Santana, E.; Hermida, L.; Guillén, G.; Guzmán, M.G. Serotype-specificity of recombinant fusion proteins containing domain III of dengue virus. Virus Res. 2008, 138, 135-138. [CrossRef]

245. Osorio, J.E.; Brewoo, J.N.; Powell, T.D.; Arguello, J.; Huang, C.Y.-H.; Kinney, R.M.; Tary-Lehmann, M.; Silengo, S.J.; Livengood, J.A.; Moldovan, I.R.; et al. Efficacy of a Tetravalent Chimeric Dengue Vaccine (DENVax) in Cynomolgus Macaques. Am. J. Trop. Med. Hyg. 2011, 84, 978-987. [CrossRef]

246. Strouts, F.R.; Popper, S.J.; Partidos, C.D.; Stinchcomb, D.T.; Osorio, J.E.; Relman, D.A. Early Transcriptional Signatures of the Immune Response to a Live Attenuated Tetravalent Dengue Vaccine Candidate in Non-human Primates. PLoS Negl. Trop. Dis. 2016, 10, e0004731. [CrossRef] [PubMed]

247. Suphatrakul, A.; Yasanga, T.; Keelapang, P.; Sriburi, R.; Roytrakul, T.; Pulmanausahakul, R.; Utaipat, U.; Kawilapan, Y.; Puttikhunt, C.; Kasinrerk, W.; et al. Generation and preclinical immunogenicity study of dengue type 2 virus-like particles derived from stably transfected mosquito cells. Vaccine 2015, 33, 5613-5622. [CrossRef]

248. Huang, K.-J.; Li, S.-Y.J.; Chen, S.-C.; Liu, H.-S.; Lin, Y.-S.; Yeh, T.-M.; Liu, C.-C.; Lei, H.-Y. Manifestation of thrombocytopenia in dengue-2-virus-infected mice. J. Gen. Virol. 2000, 81 Pt 9, 2177-2182. [CrossRef] [PubMed]

249. Shresta, S.; Kyle, J.L.; Snider, H.M.; Basavapatna, M.; Beatty, P.R.; Harris, E. Interferon-dependent immunity is essential for resistance to primary dengue virus infection in mice, whereas T- and B-cell-dependent immunity are less critical. J. Virol. 2004, 78, 2701-2710. [CrossRef]

250. Shresta, S.; Sharar, K.L.; Prigozhin, D.M.; Beatty, P.R.; Harris, E. Murine Model for Dengue Virus-Induced Lethal Disease with IncreasedVascular Permeability. J. Virol. 2006, 80, 10208-10217. [CrossRef]

251. Schul, W.; Liu, W.; Xu, H.; Flamand, M.; Vasudevan, S. A Dengue Fever Viremia Model in Mice Shows Reduction in Viral Replication and Suppression of the Inflammatory Response after Treatment with Antiviral Drugs. J. Infect. Dis. 2007, 195, 665-674. [CrossRef]

252. Orozco, S.; Schmid, M.A.; Parameswaran, P.; Lachica, R.; Henn, M.R.; Beatty, R.; Harris, E. Characterization of a model of lethal dengue virus 2 infection in C57BL/6 mice deficient in the alpha/beta interferon receptor. J. Gen. Virol. 2012, 93 Pt 10, $2152-2157$. [CrossRef] [PubMed]

253. Perry, S.T.; Prestwood, T.R.; Lada, S.M.; Benedict, C.A.; Shresta, S. Cardif-mediated signaling controls the initial innate response to dengue virus in vivo. J. Virol. 2009, 83, 8276-8281. [CrossRef] [PubMed] 
254. Perry, S.T.; Buck, M.; Lada, S.M.; Schindler, C.; Shresta, S. STAT2 Mediates Innate Immunity to Dengue Virus in the Absence of STAT1 via the Type I Interferon Receptor. PLoS Pathog. 2011, 7, e1001297. [CrossRef]

255. Guirakhoo, F.; Pugachev, K.; Zhang, Z.; Myers, G.; Levenbook, I.; Draper, K.; Lang, J.; Ocran, S.; Mitchell, F.; Parsons, M.; et al. Safety and Efficacy of Chimeric Yellow Fever-Dengue Virus Tetravalent Vaccine Formulations in Nonhuman Primates. J. Virol. 2004, 78, 4761-4775. [CrossRef] [PubMed]

256. Guirakhoo, F.; Zhang, Z.; Myers, G.; Johnson, B.W.; Pugachev, K.; Nichols, R.; Brown, N.; Levenbook, I.; Draper, K.; Cyrek, S.; et al. A single amino acid substitution in the envelope protein of chimeric yellow fever-dengue 1 vaccine virus reduces neurovirulence for suckling mice and viremia/viscerotropism for monkeys. J. Virol. 2004, 78, 9998-10008. [CrossRef] [PubMed] 